\title{
To Trim a Torch: Modeling Pause in British Women's Gothic Fiction
}

\author{
Malcolm Thaine Bare \\ Summit, New Jersey
}

BA English (Honors), BA Psychology, Rutgers University, 2014

A Thesis presented to the Graduate Faculty of the University of Virginia in Candidacy for the Degree of Master of Arts

Department of English

University of Virginia

May, 2016 
How does one write gothically? Criticism regarding the gothic novel's emergence casts the genre's development as either a Draculaic, endemic bloodline or a Frankensteinian amalgamation. For Maggie Kilgour, the latter suffices, writing that while Ann Radcliffe "was an important authority for later writers, she too had created a force she could not control" (186). Kilgour's The Rise of the Gothic Novel surveys a now familiar trajectory, dating from Walpole to Godwin to Lewis on the male side and Wollstonecraft to Radcliffe to Shelley on the female. The work poses the genre as being intricately informed by Rousseau and Burke, but spoiled ultimately by a deluge of aesthetically-minded copycat texts that corrupted the high-minded project into derelict castles, creaking doors, and complex property inheritance plots. More recently, Michael Gamer and Dale Townshend have prioritized the burgeoning lending library's contribution to the genre's development; figures such as the Minerva Press's William Lane have started to gain long due recognition and notoriety for their integral role in disseminating gothic fiction. Gamer suggests that the commercialized Gothic transcends the kind of philosophical cocktail Kilgour presents, existing rather as a "dynamic and heterogeneous" aesthetic (8). This thesis does not aim to reassess the Gothic's muddled origins or its familiar aesthetic; Kilgour sees Shakespeare and Samuel Richardson, Ian Duncan sees early modern Romance, and others point to Irish folk culture and Italian romance. No one questions the richly intertextual, multimedia, and global web that constitutes and distills itself into the great eighteenth-century gothic canonical novel. Yet, in discussing the genre, we have traced so much background for so very few books, dismissing the rest as a series of contrived plots and mechanisms.

A philosophically steeped crowd did not write or read most Georgian gothic novels, 
though, nor did they seek to intricately weave together sensation with the decadent, nonmimetic, and ancestral qualities of Romance (Duncan 7). A survey from several Minerva Press gothic novels' prefatory sections reveals an authorship motivated predominantly by supporting their children or disabled spouses who had returned from the continent, disfigured and unable to work. Karen Morton, one of the handful of critics who has recently written on Eliza Parsons, one of the Minerva Press's most prolific writers, sums up the situation: "In literature and life...Parsons trie[d] on new roles, depending on her current specific purpose... but behind every new attempt lives the specific, unwavering goal of earning enough to feed, clothe, house, and educate her large family" (Morton 35). We may be rightly suspicious of some claims to dependency that preface the Minerva Press novel, yet they nonetheless prepare the reader for works written by necessity rather than highly intertextual and critically conversant art. These are orphan texts that grabbed what they could from Mrs. Radcliffe's garden rather than groomed, blood-related daughters taught to tend the soil. We should embrace these writers by reevaluating the notion that the Gothic is an "extremely allusive form that is conscious of its own literary relations" (Kilgour 39). The literary relations critics focused on were these novels' repetitive, formal features that seemed to capture the aesthetic gloss and trappings of Radcliffe's works, but not their philosophical soul. Indulging in Kilgour's metaphor momentarily, the Frankensteinian monster's heirs knowingly bore his horrifying looks, but had taken little to none of the Milton or Greek to heart.

Did the gothic novel fall victim to the post-Udolpho copies or did it find means to survive in a latent way? This thesis contends the latter. Several charts depict the gothic novel reaching its high water point in the 1800 s before slowly disappearing into the 
century's first two decades (Potter 43,47). Instead, I recommend that the genre became a hyper-efficient, self-sustaining, and idiosyncratic essence. Sharon Marcus has joined others in recently suggesting that a "strain" of the Gothic can be found among all nineteenth century women's novels, while Nancy Armstrong posits that the Gothic serves as realism's necessary counterpart. Codifying this strain necessitates more than delimiting the Gothic to the unrealistic and fantastical. I assert that we partially see a decline of the gothic novel, then, in that the assimilation and reproduction of the form developed a literary bouillon concurrently with the full-bodied stock; as Kilgour writes, "the rapidity with which... [the] revolutionary literary form became reactionary seems astonishing" (42 - 43). We may see the large hunks of vegetable and bone in the crumbling stone staircases and flashes of lightening, but the essence that contains the Gothic passes liquid through the sieve of genre studies.

In reviewing Henry James's The Turn of the Screw, Virginia Woolf postulates that the work possessed a gothic essence comprised of "the baffling things that are left over, the frightening ones that persist" (James 159). Aesthetics carry an intricate and monstrous baggage that fail to fully encompass the less exemplary Gothic. But we must wonder what else Woolf is doing when, in her own ghost story "A Haunted House," she writes "Yet, the moment after, if the door was opened, spread about the floor, hung upon the walls, pendant from the ceiling—what?" (3) This project seeks to uncover the baffling and persistent features that exist outside of the aesthetic realm; if not the ghosts or the antique or the sound of feet on staircases - what? Lexically and syntactically, gothic writing transcends its familiar trappings and medium. Gamer calls the Gothic a site that "moves, and must be defined in part by its ability to transplant itself across forms and 
media" (4). Movement can only occur through a syntactic core capable of rapidly expanding and compressing itself; the Gothic abandons some of its familiar aesthetic conventions, even the philosophical tenets that undergird it, to reach an increasingly vast, eventually global, audience across mediums. Whether it be in the novel, the theatrical, short story, or poem, Radcliffe's distinctive style of writing defines the genre's formation and afterlife; her lines set the precedent that her immediate imitators altered into the literary shorthand we recognize even in Woolf's work. This immediately suggests the obvious: Minerva Press writers maintained and tweaked the weight and construction of Radcliffe's distinctive lines as the practice's standard. More pertinent, however, is how this style of writing was evoked and transatlantically distributed throughout the long nineteenth century by the likes of the Brontës, Brownings, Gaskell, Austen, and more.

The choice of Ann Radcliffe over Horace Walpole, Clara Reeve, or Matthew Lewis as the stylistic progenitor reflects the groundswell of women's gothic texts published immediately after the publication of The Mysteries of Udolpho, the author's fame (over notoriety), and the text's markedly larger afterlife in the Victorian period. While Gamer suggests that "Lewis's reception and the reputation it created significantly shaped [the] gothic's status and identity" (88), the text's more risqué features, let alone style, were inaccessible to the lion's share of anonymous, female authors; even if we treat The Monk and its reception as the gothic form's hallmark press event, Radcliffe's large corpus and influence on Lewis's work stylistically remained paramount. If we are to theorize gothic stylometry, we must start in the mid-1790s when the gothic novel and theatrical were nearing peak popularity. Michael McKeon notes that "theory develops in a dialectical relation to genre as a supplementary discourse of detached commentary that is yet 
inseparable, in its own development, from the corollary process of genre formation" (118). Beginning at The Castle of Otranto ignores its one-off, experimental nature; a sleeper agent, maybe, but no billboard hero. While Kilgour brilliantly traces a smooth philosophical lineage from Otranto to Frankenstein, the absence of a majorly popular, aesthetically gothic, and Anglophone novel between Otranto and Radcliffe's works depicts the former as an aberration rather than a model.

To make the claim for a syntactic and lexical gothic style, this thesis's first chapter couples a series of digital experiments centered around the Minerva Press's history and house style. Using Cluster Analysis, I compared the degree of similarity between twenty "imitative" novels published from between 1795 and 1803 with Ann Radcliffe's The Mysteries of Udolpho and Matthew Lewis's The Monk. From there, I performed an author attribution study on one of the press's most popular novels, Lusignan, testing the claim that it was written by Radcliffe herself and finding which syntactic features came to constitute the gothic sentence. If Minerva Press authors were imitating the works of Ann Radcliffe, studying Lusignan's formal construction helps to answer what remained and shifted beyond aesthetic and architectural features. Put simply, if female Minerva Press authors were writing to support their families, what shortcuts did they take? The chapter seeks neither to answer what the gothic novel is or does, let alone chart its 'rise', but to argue that it began a process of syntactic and lexical shrinking within years of Udolpho's publication necessary for its politicization in the Victorian period.

After establishing this stylistic core, chapter two will address its increasing mutability and portability in the global Victorian periodical and poem, looking specifically at one of Elizabeth Gaskell's short stories and Elizabeth Barrett Browning's 
Aurora Leigh. I attempt to answer how the stylometric afterlife of the Minerva Press authors' syntactic shortcuts inevitably increased the form's range of applications later on. The choice to focus on periodicals and epic poetry rather than the novels of the Brontë sisters is deliberately made to explore the form's efficacy when newly relegated to the supplementary; while we encounter gothic episodes in Jane Eyre and Wuthering Heights, I argue that the pure gothic exists in miniaturized, portable forms sustainable outside the novel by the time we reach the Victorian period. Nancy Armstrong suggests that by the turn of the century "the novelist who relied on exotic situations and extravagant emotionalism for audience appeal would be found lacking by the new standard" (6). In The Physiology of the Novel, Nicholas Dames offers that "the novel of the nineteenth century trained a reader [to be] able to consume texts at an ever faster rate, with a rhythmic alternation of heightened attention and distracted inattention locking onto ever smaller units of comprehension" (7). As nineteenth-century audiences read more quickly and were better versed in the tropes and hallmarks of the genre, this section asks first how the Gothic accommodated this readership, but more, how it responded to newfound, transnational political agendas. The economy of "periodic energies" and "small discharges" that constitute the novel reading experience (Dames 54) needed to be refigured, given the shrinking space.

The syntactic core that ties Ann Radcliffe to published imitators like Mary Ann Radcliffe or Ms. Ratcliff, Gaskell to Brontë to Barrett Browning cannot be totalized or diagrammed by the strictures of a 'female Gothic' tradition; the vivid whole that binds these texts exists in their successive, additive way to style and generate a pause. Even in its smallest, most diminutive form, the Gothic affords a break, though one that never was 
uniform: for Radcliffe, rest is illusory with commas and semi-colons compounding the mystery of a distant sound, while Gaskell employs uncannily repeated phrases and Barrett Browning punctuates her gothic lines with the faces of dead women. Rarely, however, do we find these breaks granted on account of a ghostly, spectral sight. Pause occurs in Gaskell's work when the narrator picks up a phrase she heard when the servant told a tale; in Barrett Browning's work when Aurora Leigh attends a wedding and sees the pallid aristocracy. The peaks and valleys associated with the gothic reading experience - terror and retreat - are not the ties that bind and carry the form matrilineally. Rather the form continues through the incidents where little seems to occur - the moments when the torch is trimmed.

\section{I: Gothic Stylometry and Influence}

\subsection{In Name Only: The Radcliffean Title}

In August 1794, Coleridge wrote in regards to Ann Radcliffe's The Mysteries of Udolpho, "Four volumes cannot depend entirely on terrific incidents and intricacy of story" (Nixon 291). Udolpho was Radcliffe's fourth and most popular novel. She began her novel writing career in 1789 with The Castles of Athlin and Dunbayne, taking hold of the public's attention with 1791 's $A$ Sicilian Romance. Nevertheless, most critics agree that it was Udolpho that brought about the "deluge" of imitators (Gamer 50). While The Castle of Athlin and Dunbayne arrived within a year of the second printing of Walpole's Otranto, its effect was significantly less profound than what followed five years later. Udolpho's publication not only inspired a variety of similarly-named copy cats and false 
claims to authorship, but influenced genres other than romance. While we know the Gothic to be the dominant form of the 1790s novel, this section contends that the more superficial characteristics of Radcliffe's work, such as length and titles, impacted a number of contemporaneous travel narratives and histories. The footprint of the Radcliffe-imitative novel expanded well past fiction into more realistic categories through basic, superficial stylistic features. While Radcliffe set the precedents for this convergence of form, it was cemented by the proliferation of substantive changes made by publishers.

At the Minerva Press, for instance, the catalog of published titles appears to be significantly more diverse from the 1789-1794 period than after Udolpho's publication. William Lane founded the Minerva Press in 1773, but did not begin actively publishing fiction until the 1780s. After purchasing the newspaper, The Star and Evening Advertiser, in 1788, Lane took a far greater interest in his press, issuing forth calls for "Novels, Tales, Romances, Adventures, \&c" $(18,48)$ within the periodical. He published a number of histories, travel narratives, and even some operas throughout the eighties; the press was in an "experimental stage" (39) where a variety of publications were accepted, spurred by the new vehicle for advertisement and a more spacious change of address to Leadenhall Street. During the first four years of the 1790s, he published a diverse catalog of texts that had little resemblance to Athlin and Dunbayne or A Sicilian Romance in terms of name or content. Travel narratives such as Trip to Weymouth (1790) and Richard Twiss's A Trip to Paris (1792) joined histories like Anna Mackenzie's Danish Massacre (1791) in comprising a large portion of the press's portfolio (Blakey, Appendix II). After 1794, the titles of both Minerva Press novels and nonfiction works acquired a 
distinctive, homogenizing Radcliffean gloss, regardless of genre. Lane's works were immensely popular in circulating libraries where subscribers clamored for more like Udolpho. This wish was partially fulfilled. The publisher gave travel narratives, romances, and histories nearly indistinguishable titles with works such as Phantoms of the Cloister, Mysteries Elucidated, Orwell Manor, Horrid Mysteries, Mysterious Warning, Mystery of the Black Tower, and Mystic Castle (1795-1796) lining shelves. Yet the press also repackaged existing works to attract a Radcliffe-loving audience in addition to flooding the marketplace with imitators. One particularly odious instance of this Radcliffe-inspired branding occurred when The Victim of Magical Delusion was republished as Horrid Mysteries by the press a year after its first printing, only this time with a frame narrative that suggested the tale was translated from German (Smollett 473, 1797). A.M. Mackenzie's Mysteries Elucidated veered from the traditional historical novel she was celebrated for through the inclusion of a variety of sensational scenes of terror and spectacle (Smollett 546). Travel narratives regarding castles and abbeys began, too, to include more spectral and spectacular incidents that tested the limits of nonfiction. These noticeable, substantive alterations joined the Minerva Press's novel's doling of buzzword-like titles that syntactically or lexically resembled prominent works, helping to promote both new and recycled texts; titles were close enough to misrecognize or, in the case of 1798's The New Monk, be sold as successors. Critics tended to be more favorable to the less lengthy variety of these works that were purpose-built for the lending library. John Palmer's two volume The Mystery of the Black Tower was "favourable[ly]" designed, managing to balance "graver scenes" with unique "flashes of humour" in its two volumes (Smollett 435, 1796); critics praised Manfredi (1796) for seeming to be 
authored by "a disciple of Mrs. Radcliffe" who was capable of approaching the "height of terror" (Smollett 433, 1796).

Yet the only author whom the Minerva Press's holistic embrace of the Gothic was beneficial to in the long run was Radcliffe herself: her exceptionalism was noted both by her contemporaries as well as through her continued relevance today. A review of Mysteries Elucidated advised its author that its “censure implied on Mrs. Radcliffe's work [proved] futile" (359). No alterations to titles, incidents, or history were able to produce a Minerva work that received a similar level of praise or commercial success, especially those like Mysteries Elucidated or T.J. Curties Ancient Records that unsuccessfully provoked direct comparison or revision to Udolpho's author. Nevertheless, these novels remained wildly popular, particularly original works, with some prominent figures like Coleridge referring to works like The Beggar Girl as "the best novel me judice since Fielding" (Blakey 54). While recent critical works surrounding the Northanger Abbey novels have attempted to elevate Eliza Parsons from the pack, the lion's share of interest in the press has surrounded its connection to Ann Radcliffe.

Whether or not we can call what the Minerva Press attempted to copy from Udolpho gothicness is another story. William Lane's campaign to rename texts aided in expanding the affordances and machinery we expect from the genre; by attaching gothic titles to a variety of published material, Lane unintentionally corroborated with many of Udolpho's terror-less features. These features provoked Terry Castle to question Udolpho's success as a "Gothic" novel, arguing that to label the novel such would be "inevitably to reduce it" to its "gloomy, macabre, and medieval" setting (Radcliffe vi). 
Emily St. Aubert's exploits in the Castle Udolpho constitute a rough third of the novel, with the other two sections focusing on her parents' deaths, her romance with Valancourt, and her reconciliation with the terror she experiences within the castle. If we emphasize the importance of these sections, seeing Udolpho not as the refinement of Walpole's Gothic "prototype," but as its own kind of admixture, components become immediately recognizable. Lane's ability to rebrand historical fiction and travel narratives as Udolpholike texts reflects the work's compatibility with and amalgam of various popular literary forms. For instance, Radcliffe's novels were ripe to be adapted into various nearmelodramatic theatricals, inspiring two stage adaptations in English and one in French within three years of its publication. These featured hallmarks that Matthew Buckley and other critics associate with melodrama: an orphaned, exiled protagonist, incidental music, lavish scenery, clear aristocratic villains, and other theatrical touches. With Udolpho's publication there was 'a sharp increase in the Gothic 'product' [plays, novels, and poetry]" that had started in the late 1780s (Miles 42) with "two to six Gothic dramas performed each year" (Cox 126). Ingrid Horrocks refers to Udolpho as a "blended" novel, a phenomenon of "novel[s] that incorporate[d] actual verses and lyric moments... [that were] a distinctively 1790s form of heteroglossia" (507). Lane, through titular renovation, capitalized on this frenzy in the short run, yet expanded the genre's capabilities in the long run.

Yet the Minerva Press's huge renaming endeavor points specifically to the totalizing effect of Radcliffe's popularity; while we could find poetic, travel, historical, musical, and theatrical elements in the works of Ann Radcliffe, the titles of her novels altered the titles of these works. This is the gothic strain in its earliest and most 
superficial form; to title a work with the words "Abbey", "Castle", "Mystery", "Horror", "Phantom", "Ruins", "Forest", or "Ancient" after Udolpho was to draw immediate comparison, regardless of genre. Granted, this convention did only last half a decade after the turn of the century. As Franco Moretti shows, the titles of novels decreased in word count dramatically throughout this period (185). This renaming strategy, however, proved immensely profitable for Lane, who was known to trot around London with a golden cane at the time. Moreover, it benefitted the bevy of female authors who Thomas Wilson claims "might never have appeared, nor [had] their labours rewarded, but for Circulating libraries" (Nixon 221). Wilson goes on to suggest that the volumes produced for circulating libraries were crucial for encouraging auto-didacticism in the poor and a love of novel reading in the immoral. While critics panned many of these works for their seemingly "unnatural" decisions to include unrealistic "incidents" in no spectacular style, the circulating library subscribers seemed not to care.

Gamer suggests that "the greater the divide between the Gothic and the genre or form that it enters, the greater the chance that the appropriation will be read as a generic impurity" (12). Yet we can also approach Radcliffe's titular invasion into the historical novel as paving the way for Sir Walter Scott decades later; its spectralizing of the travel narrative can be credited for a newfound interest in the ruin's function to store memory; or even the early gothic theatrical's transformation into the family melodrama in the 1820s. Regardless of any impurities Lane's alterations may have produced in generic conceptions, the Radcliffean Minerva Press novel served a critical role in fashioning and providing access to burgeoning modes of narration. 


\section{2: Clustering: The Gothic Progenitor and Her Heirs}

Attributing a multimedia sea change to a single novel's publication invites skepticism that a list of titles, historical context, and contemporaneous reviews could not hope to satisfy alone. Radcliffe's fourth novel built upon and was built upon by other successful works; The Mysteries of Udolpho was joined by Matthew Lewis's controversial The Monk years later, alongside Radcliffe's own response novel, The Italian. If we consider the multimedia frenzy that was the 1790's gothic work, crowning a single canonical text the form's prime mover presents difficulties that pure historical context cannot sufficiently cover.

One method to remove these prejudices exists in the digital techniques of Cluster Analysis and Principal Component Analysis. Ardunay and Sporleder suggest that using clustering for genre reveals how "the stylistic signature of every document corresponded to a strong 'author' signal, rather than to the 'genre' signal" (32). This section aims not to classify several Minerva Press works as Gothic, but to elucidate their degree of belonging to what Wordsworth terms "the Radcliffe school" (Townshend 14). I performed a series of three cluster analysis experiments to eliminate, if only partially, the self-confirming bias associated with digital projects: one where The Italian serves as the the central node for comparison, one where The Monk serves this role, and one where The Mysteries of Udolpho stands center.

More recent approaches to clustering have sought to arrange and relate novels through character networks and locales. While tropes like the gothic heroine, gothic villain, and, of course, the valiant hero are well-known, far more detailed work has been 
done to determine those features in traditional scholarship; the works of Watt, Kilgour, Gamer, and Miles - even Jane Austen herself - established that most gothic novels revolve around an orphaned protagonist, a foreign setting, distance from the present day, etc. What we don't know, however, is how syntactically and lexically similar these texts are. If we look at the make up of sentences and percentages of words without generic preconceptions, how closely do these texts resemble one another?

I sampled twenty post-1796 gothic novels. These books were published both by The Minerva Press and fellow publishers that also profitted from the gothic craze. PDF versions of these texts from GALE Cengage's Eighteenth-Century Collections Online were downloaded and OCR'd through ABBYY FineReader. While corrected, full text editions of these works aren't available, copies of Udolpho, The Monk, and The Italian were retrieved in a similar process to avoid mixed results. All of the texts compared suffered largely from OCR errors, the most prominent being the replacement of the long 's' with an 'f.' Using word n-grams proved to be wildly inconsistent given how unique certain OCR errors can be; for instance, several title pages with the word "press" were rendered as as "prefs," "preG," "pre33," etc. Individual words, then, proved to be a far more accurate measure. The first trial was run using a Weighted Euclidean Distance (WED) to measure how far the novels would measure from one another in terms of raw word frequency usage. Canonicizers, algorithms that preprocessed .txt files before testing occurred, normalized the white space in the texts, eliminated punctuation, and standardized the case of all words.

I ran the first sample trials in JGAAP to measure the WED between clean .txt files of known authors, finding what score range would typically constitute authorship. For 
instance, using the same text preparations as listed earlier except with clean full text files retrieved from Gutenberg, Radcliffe's Udolpho measured a .014 distance from The Italian, while it scored .019 when compared to Fielding's Tom Jones. Charlotte Brontë's Jane Eyre scored a surprisingly diminutive .008 when compared to Villette, while Jane Austen's Pride and Prejudice scored a .012 when compared with Emma. When Pride and Prejudice was compared to Jane Eyre, it scored a .022. The WED's closeness to zero, then, served as a rough measure to indicate stylistic similarity in Most Frequent Word (MFW) choice. Scoring below .015 was typically reserved for texts with strong similarities, while .025 indicated a vaguer association. Scores above .025 were typically from novels of different periods and traditions with the highest score being generated when a clean copy of Jean Rhys's Wide Sargasso Sea was compared to Jane Eyre. It's important to note that these scores are relative and vary greatly depending on the corpus included; a .020 between Caribbean novels can be more likely to show authorship than a .012 between nineteenth-century Anglophone works, for instance.

The results were unsurprising: Radcliffe's Udolpho scored lower than either The Monk or The Italian on sixteen of the twenty novels. Matthew Lewis's The Monk scored the lowest for three of the twenty novels, notably all written by male authors, while The Italian scored one, but often maintained a score straddling between the other two novels (Appendix 1.1). Lusignan stood out by scoring nearly as close to Udolpho as Radcliffe's own The Italian. As for the outlier, The Castle of Beeston, contemporary reviews help shed light on its relative distance from both authors' works; apart from being a historical romance rather than a pure gothic novel, The Monthly's reviewer accuses the text of being full of "obscure grammatical inconsistencies" and "diction rendered tumid" (90). In 
addition to the margin of error we expect from using OCR copies, The Castle of Beeston's generic difference and idiosyncratically poor writing style could have prevented it from achieving similar clustering to other works.

Reviewing the data, the margin of difference between any of these authors' works and Radcliffe's is significantly higher than when clean copies were compared head on. If we compare a clean copy of Udolpho to The Monk, the score approaches a .014, while OCR'd versions of the same novels net a .022. This margin of error would be unacceptable for a detailed author attribution study, as we'll see in Section 1.3. Still, these texts can still teach us about general trends. In a recent article, Macijej Eder suggests that in larger corpora (much like the one we're using), measuring the delta for the 100 MFWs doesn't noticeably change, even if the OCR'd copies used are over twenty percent damaged (Eder 612). The .008 disparity we see when clean and dirty copies of The Monk and Udolpho are compared directly lessens in significance when a larger, dirtier corpus is used. This sample begins to elucidate Wordsworth's notion of the Radcliffe school of writing compared to other possible influences; both The Mysteries of Udolpho and The Italian scored far closer to these twenty texts than The Monk. While it's unlikely that we'd find the same degree of idiosyncrasy in these OCR'd gothic novels as we would in clean copies of Brontë's works, the sampled novels' trend towards Radcliffe's popular work is unmistakable.

A second trial was performed in R-Stylo, using Principal Component Analysis to compare the novels on the basis of the $1000 \mathrm{MFW}$. Some stylometrists have recently found a larger number of MFW to be a better indicator of stylistic similarity (Rybicki and Eder). Results here, surprisingly, were similar to the earlier trial; a large number of the 
novels clustered around or near The Mysteries of Udolpho, while both The Monk and The Italian, though close, were off center (Appendix 1.2). Lusignan was once again the closest text to Udolpho of the non-Radcliffe works, while Eva and The Spirit of Elbe served as outliers. This trial was important for visualizing how closely these texts arranged themselves toward one another.

Cluster Analysis was used for the third trial, with Burrow's Delta and the $50 \mathrm{MFW}$ being employed. While both raw statistics and PCA can reveal some trends, Cluster Analysis forms a dendrogram that groups and pairs like novels. R-Stylo rightly paired The Italian with Udolpho first (as measured by line length on the $\mathrm{x}$-axis) and in the center (as measured by its place on the y-axis). Notably, it categorized Lusignan beside predominantly male authored texts (Appendix 1.3). We see two distinctive clusters form around 1.5, notable for including none of Radcliffe's works. One interpretation of this would be a sort of syntactic idiosyncrasy in Radcliffe's writing that caused the imitators to pool together before clustering with her own work around 1.75. Once again, The Spirit of Elbe and Eva were outliers, joining the cluster relatively late.

Through these three statistical measurements, we can assert that Ann Radcliffe's The Mysteries of Udolpho had a prevailing influence that exceeded either her later works or contemporaneous rivals when word usage is measured. While this sample by no means covers all of the novels published after these major works were, Udolpho's consistent spot in all three trials correlates with the critical consensus that it was the novel that served as the decade's precedent. More importantly, however, we see Radcliffe's later three novels, The Romance of the Forest, Udolpho, and the Italian, comprise a close-knit, syntactic core. Once cleaned up versions of these all-but-forgotten imitators are made 
available, either through more accurate OCR technology or the work of editors, this study would benefit from being revisited. Until then, we can say, with some certainty, that Udolpho rather than The Castle of Otranto, The Monk, or The Italian served as the staple, mother text for most Anglophone novels and short works that followed.

\subsection{Author Attribution: The Mysteries of Lusignan}

A recent printing of Lusignan or The Abbaye of La Trappe includes Ann Radcliffe's biographical information on its back cover, cheekily reading "after publishing The Italian, at the height of her powers, Radcliffe disappeared from the literary scene and never published another novel. Or did she?" She did: Gaston de Blondeville (1826). But Ann Radcliffe likely did not write Lusignan, unless she was working on the wildly experimental Gaston, purported to have been started in 1802, simultaneously with the arguably more traditional Lusignan. We cannot, however, blame publishers. If one employs both modern stylometric and author attribution techniques, as this section does, the anonymous Lusignan not only matches Radcliffe's oeuvre more than Gaston, but more than several of her other novels.

Such issues are, however, common to the field of stylometry. John Burrows used similar, extensive procedures on Shamela and Pamela suggesting that imitative texts present "a stern challenge to several current tests of authorship" (437-438). If we perform the same procedure on these novels as we did in the previous section, Shamela scores a .012 with Pamela, the same score as Emma when compared to Pride and Prejudice. Even when a comprehensive suite of techniques is employed, indicators of 
authorship can be null and void when conscious imitation is performed: in a recent experiment performed at Drexel University, forty-five participants, asked to imitate Cormac McCarthy's prose style, were able to pass all author attribution tests when JStylo compared their samples to The Road (Brennan). As the previous section shows, Radcliffe's work influenced its fair share of forgotten gothic novels. Lusignan's afterlife, namely the continued debate between Jacqueline Howard and Dale Townshend over its author's identity, presents an especially strong case study for marked syntactic similarities. If Lusignan is simply a novel that "self-consciously attempted to copy and emulate the Radcliffean mode" (Townshend 14), it is key to deciphering the genre's stylistic core, or rather, what remains unique when we come the closest to an established form. This section attempts to combine historical context with a variety of author attribution tests to provide as conclusive a study as possible of Lusignan's legacy.

Lusignan was never reviewed, but a novel attributed to its same author, The Ophans of Llangloed, was written about in 1803. Published only a year after Lusignan, Llangloed was approached by reviewers purely as a purpose-built Minerva text: "These volumes will not be an unwelcome present to the circulating library" (Smollett 237). The novel was praised for its "sprightly" style and "pleasing" events, but received its highest accolades for the author's supposedly deft employment of regional dialect through its main villain, Mr. O’Shallaghan. He attempts to abduct the Countess of Glendower to Southern Ireland, as recounted in one of the novel's epistles, intermixing his devious plots with the occasional exclamation of "Jasus!" Such a text, with its epistolary form, crudeness, and non-continental western European setting, veers sharply from most of Radcliffe's works, even Lusignan itself. While Jaqueline Howard suggests that 
Lusignan's "uncannily Radcliffean" features, including "marked similarities of imagery, diction, and intertextual reference" (xlix), produce what's all but certainly one of Radcliffe's works, her case for Llangloed is far less cut and dry. Howard's evidence involves no attempts at stylometry, but rather a diligent culling of scenes, settings, and characters from both texts that are especially reminiscent of Radcliffe's previous works. On occasion, her case is less than convincing; characterizing "the workings of divine justice and the effects of melancholy" (Howard III) as distinctly Radcliffean themes does a large disservice to contemporaneous works. Whether these works were written by Radcliffe or not, they deserve more critical attention to discover someone who could write like Radcliffe significantly better than her peers.

The strongest piece of evidence that Ann Radcliffe was neither book's author involves the relatively opportunistic relationship between her name and the Minerva Press. Howard's essay doesn't extensively cover this issue, but she concludes by quickly flourishing that "Whatever the case, in the oppressive cultural climate of war-weary Britain, resort[ing] to anonymity with the Minerva Press protected the author of Lusignan and The Orphans of Llangloed from censorious and carping critics, and ensured access to a large audience" (V). Radcliffe's novels were celebrated and the public was clamoring for more of her works; though reviews of The Italian were slightly less enthusiastic than of Udolpho, labeling the author's hesitance to publicly publish her work on account of an oppressive culture climate reaches too far. On a purely financial level, Radcliffe received $£ 500$ for the publication of Udolpho in 1794, while the Minerva Press's going rate was between "five to one hundred guineas" with Blakey speculating that few, if any, ever reached the larger end of that spectrum (73); Rees suggests that $£ 10$ to $£ 20$ was the going 
rate (87). One would have to believe that Radcliffe had little interest in capitalizing on a triumphant and eagerly-anticipated return to novel writing had she signed a contract with William Lane.

Moreover, it's difficult to think that Radcliffe would align herself with a press that attacked her authorship on several occasions and profited from novels falsely attributed to her, such as the works of Mrs. Elizabeth Ratcliffe and Mrs. Mary Ann Radcliffe; the latter was credited with writing the previously anonymous The Fate of Velina de Guidova (1790) and Radzivil (1790), which were later republished from 1814 (Bonhams) to 1878 (Blakey 53) as “Mrs. Ratcliffe's." The Minerva Press attempted to take credit for publishing Radcliffe's work after her success, but also before it. While Howard presents the Minerva Press as a place where an author like Radcliffe could experiment with the wildly different Lusignan and Llangloed, she would have had more lucrative, let alone supportive options almost anywhere else. Given that the press performed nearly every possible scheme to replicate and misattribute her texts, we can be somewhat certain that Radcliffe never published any of her work with them.

I performed several digital experiments to help substantiate this claim. Five of Ann Radcliffe's best known novels were chosen to comprise her corpus for these experiments: The Castles of Athlin and Dunbayne, The Romance of the Forest, A Sicilian Romance, The Mysteries of Udolpho, and The Italian. Three randomly selected samples of 10,000 words each were taken from each novel, providing a total of fifteen samples of Radcliffe's writing. Radcliffe left no letters or journals after her death, although one letter from her to her mother-in-law was recently discovered by the British Library (Flood); very little material exists to create a corpus for the author outside of her novels. Gaston 
de Blondeville was excluded from these tests on account of its 1826 publication; even if it was written in 1802, the Minerva Press had changed drastically both in content and management by 1826 . The Minerva Press texts exist primarily as scans, leaving OCR as the only option to access them. A recent, corrected publication of Lusignan allowed a clean copy of the text to be used in experiments. This edition was scanned and run through OCR, with the publisher's permission, making it a prime candidate for these experiments. Given Llangloed's stylistic differences and unavailability as a corrected digital text, it was excluded from these experiments.

When looking at the fifty most frequently used words, Lusignan fits into Ann Radcliffe's corpus better than her first work, The Castles of Athlin and Dunbayne. Using Voyant, Radcliffe's five novels and Lusignan were compared on the basis of word frequency (Appendix 2.1). The fifty most common function words were initially chosen from the corpus for comparison and sampled throughout. The standard deviation of these is approximately 245.26 words per 10,000 words, with the mean being 4698.76. Lusignan was the second furthest from the mean, but was notable for sharing the lowest number of common words with the corpus. It's difficult, however, to suggest that word count alone is a faithful indicator of stylistic similarity; Matthew Lewis's The Monk scores a 4619.12 per 10,000 words when added to the corpus, faring even better than Lusignan. When James Joyce's Ulysses was added as a control, it scored significantly lower at 3803.05 words per 10,000. Lusignan falls within the appropriate range of late eighteenth and early nineteenth century popular Gothic fiction, but is not exceptional by any measure.

For the second experiment, I attempted to identify the gender of Lusignan's author by adding gender metadata to the corpus as PCAs and Cluster Analyses were performed 
in R-Stylo. Twenty-nine eighteenth- and nineteenth-century British novels were added to the corpus, including The Monk, The Castle of Otranto, and The Old English Baron. Burrow's Delta was used to measure the $100 \mathrm{MFW}$. In Appendix 2.2 and 2.3, we can see Radcliffe's later novels begin pairing independently before Lusignan and The Monk join. While the eight texts form a cluster, the Cluster Analysis offers some interesting anecdotal comparisons, such as the three Brontë sisters being clustered together earlier than Radcliffe's works. The trials were repeated with all nineteenth century works minus Lusignan (Appendix 2.4 and 2.5). Once again, Lusignan and The Monk paired before rejoining with the latter half of Radcliffe's corpus. A third trial occurred with Fielding, Richardson, and Sterne omitted, leaving only what we might traditionally consider to be gothic novels. Interestingly, Radcliffe's first two novels were the outliers while all of the works produced by males clustered together. Perhaps the most damning case for the gender of Lusignan's author arrives when only Lewis and Radcliffe are left for comparison. In the PCA chart for this scenario (Appendix 2.7), a significantly stronger connection between Lusignan and The Monk is shown than between Radcliffe's own written works.

Unfortunately, Matthew Lewis transitioned to drama after the publication of The Monk, leaving behind only a fragment of a second novel, The Effusions of Sensibility, to build a larger corpus; when we add one of his most famous plays, The Castle Spectre, to the corpus it stands as a significant outlier. Nevertheless, a conclusive call about Lusignan's author's gender cannot be made from this data alone; a final trial was performed where Stoker's Dracula and Edgar Allan Poe's collected short stories were included, but Lusignan still gravitated towards Lewis first and then Radcliffe. There 
simply aren't enough 1790s influential male gothic authors with clean .txt files available to make the call.

Lusignan was a text capable of copying the features of both Radcliffe and Lewis's works; one that, when read distantly, captures the spirit of the burgeoning gothic form. Howard's praise is more than due. Attributing it solely to Radcliffe, however, delimits other exciting possibilities. For instance, the tone of Llangloed, coupled with Lusignan's closeness to The Monk, makes an altogether more convincing case for the work's being Matthew Lewis's. Not only would the infamy brought on by The Monk make him a more likely candidate to publish anonymously with the Minerva Press, but would prevent his novelistic pursuits from interfering with his career in theater. Or there could have been an extremely talented unknown author capable of shoring together the best gothic works. If we consider other factors, as the following section does, the case is less convincing that it belongs to either author. Radcliffe's works average about twenty-six words per sentence, while Lusignan stands at twenty-four; their composition varies extensively. We won't be able to identify Lusignan's author, however, until clean editions of these other lendinglibrary gothic works become available; with more potential authors and a larger dataset, we may find our answer.

\subsection{Momentary Pause: Structure and Style in the Ordinary Gothic Sentence}

Using Radcliffe's The Mysteries of Udolpho and Lusignan as primary sources, here I want to theorize and provide a case study for possible ways that the Radcliffean sentence was compressed by its successors. One demonstrable feature of the post-Monk corpus of 
imitative novels concerns their relatively short sentences as compared to Radcliffe's, averaging approximately twenty words using the corpus from Section 1.2 compared to twenty-six in Radcliffe's works. Gathering representative sentences relies on a mixture of both machine-reading techniques and new formal methodology; Radcliffe's best known sentences, laden with commas and suspense, are typically longer than twenty-six words. As we'll see in the next section with Elizabeth Barrett Browning's poetry, these most gothic-seeming sentences - the climactic reveals - can exceed fifty words. These oftparodied sentences, however, are not what this project is looking for. If Minerva Press authors copied only these hallmark moments, it's unlikely that they would have stylometrically approached Radcliffe's work quite so well during earlier PCA and Cluster Analysis tests where punctuation was removed. Much like early author attribution studies that rely on a small quantity of unique words, such an approach to Radcliffe would provide little different from what contemporary critics of these novels observed: moments of heightened, sublime sensibility during reveals that became far less exciting as the form progressed.

Rather than analyze these lengthy lines that have established the emotional peaks and valleys of the gothic reading experience, I approached the architecture of the typical sentence and its inherent, subtler motifs. These lines offer more than the dramatic, polar oscillation between terror and non-terror, but a nuanced form of suspension that we may miss when skimming. Given that a solid precedent for this kind of analysis isn't yet in place, I performed a series of procedures to theorize how we might accrue this kind of data. First, R-Stylo was run to find the fifty MFW shared between Udolpho and Lusignan. Next, an algorithm in Microsoft Word's Visual Basic Editor culled sentences 
from each novel that: 1.) Contained enough words within one digit of the average sentence length (25-27 for Udolpho, 23-25 for Lusignan; 2.) Had half of their words featured in the one-hundred shared MFW. For example, a Radcliffean sentence needed to share roughly thirteen of its twenty-six words with Lusignan to be counted. All texts were subjected to a minor alteration before being tested. Abbreviations like "St." or "Mons." were replaced with "St" and "Mons" to avoid false recognition. Sentences were then hand checked and edited: I removed those that contained fragments of dialogue. The remaining sentences were then compiled into individual text documents as well as one text document containing all three works that was then run through Mallet 2.07, topic modeling software. Afterwards, the sample sets were gone through individually and each topic was substantiated by hand.

Roughly five major functions encompass the majority of both novels' sentences: the ordinary Radcliffean sentence tracks time, travel, perception, sentiment, and a particularly fascinating amalgam of respite and reflection I will refer to as recovery (Appendix 3.1-3.5). While these concepts don't encompass all average length sentences in both novels, they cover most and operate in similar, albeit loose, patterns. This section will work through each category, examining what constitutes the most ordinary, inactive sentences in both texts. Comparing the sentence make-up of similar topics across the two novels revealed general methodologies for compression. Lusignan's sentences featured one or two commas fewer than Radcliffe's, provided unequivocal language for what characters perceived, and employed more definite action verbs. While the bulk of the sentences from both texts encompassed moments of inaction, Lusignan's lines allow the reader, paradoxically, to rest through the provision of more clearly delineated action. 
Radcliffe's sentences, on the other hand, feature a suspenseful, hovering clause that makes the prospect of respite ambiguous.

For instance, Udolpho's recovery sentences typically follow a tripartite structure where contemplation or restoration is reached in its final section after its middle portion introduces a moment that overwhelms or complicates: "In a few moments, the tide of life seemed again to flow; she began to breathe more freely, and her senses revived." Its middle part usually involves a scene of physiological overload; breath will return to lungs, a memory will overcome the body, or effort will be exerted (Appendix 3.1). During Emily's father's death, for instance, Radcliffe writes, "When he had given her his blessing, and it seemed to be the last effort of expiring life, he sunk back on his pillow." Whether it be sense leaving or surging into the actor, its impact is dramatic enough to demand recovery. Occasionally, these two positions are inverted, with respite coming from recovered trauma being compared to the current situation. Finally, the first section locates us within the scene, be it temporally, physically or with a certain character; these moments of excitement followed by respite are always site based, be that in an hour, a moment, an apartment or within an interaction. The pattern goes: location to exertion to seeming rest.

Lusignan's sentences lose some of this mass by jettisoning this locating first section and, more often than not, front-loading the curative effects of recovery (Appendix 3.2). They operate in a manner that never leaves us any doubt whether or not the dramatic middle portion we find in Radcliffe's sentences will be put to rest; whether respite will come or if instead we'll be greeted by overwhelming grief. The first three sentences listed in the appendix, for instance, begin with "When she recovered," "Sleep, which flies only 
from the pillow of guilt, soon brought relief," and "Trusting this to the care of providence." We know, in other words, that recovery, sleep, and care, are guaranteed. While this organizing principle may seem to obstruct the tension Radcliffe provides - the almost incantatory plea for respite - these sentences provide a true rest for the reader. The definiteness with which Lusignan's characters deal with recovered, painful memory denies the temporary, soothing quality of respite in Radcliffe's work in exchange for fullblown elimination; Lusignan's protagonist doesn’t momentarily relieve recurring memories, but rather declares that "[a prolonged] absence, she knew, would obliterate the remembrance of scenes, whose recollection could now be only a source of grief." By eliminating the locating portion, Lusignan denies the strictures of site-based memory challenging the efficacy of rest or remembrance. We find a gothic form that permits the hope of progress.

Also coming at the expense of memory, the scale and speed with which travel occurs in Lusignan, too, serve as a revision to Udolpho's lugubrious pacing (Appendix 3.3). The author's sentences move at "the rapidity of lightning," featuring two commas at most. Navigation occurs abruptly and with specific destinations in mind. One charming example, that imaginably might take Radcliffe a chapter to detail, reads "Lusignan asked leave to accompany his father to Paris, which was granted without difficulty, and they all set out together." Even moments of intense anticipation are belied by quick resolutions: "His heart beat when he knocked at the door; he enquired for the Count - he had left Paris early in the morning." Mobility, from these samples, is denied to the captured and contemplative with "our disconsolate exile" and his "melancholy rumination[s]" left to ponder alone by the city-bound, mobile lord. Travel isn't contingent on the need for 
emotional management, but rather, in the case of Madame di Clarival, because "the extreme heat of the weather prevented her remaining in the south." While one might argue that this oversimplifies Radcliffe's writing, it also acts as a distinctive measure of progress - Gothic with a spring in its step. Lusignan's author delimits travel and motion words to just those kinetic devices; rather than frustrate the reader with the elastic cordlike snap that confines readers of Radcliffe, Lusignan's author saves the moments of constriction for the castle.

Motion comes across as being far more tightly wound and psychologically draining in Radcliffe's novel; through ample commas joined by small spatial movements, literal stop words, and repetitive motions, Radcliffe's travel sentences purposefully get nowhere (Appendix 3.4). Mons. St. Aubert's habit of becoming sad and "frequently walking away from his companions" finds itself repeated in Emily later on. As a character, he moves nowhere distinctive, only proceeding to "where no eye could observe his grief." After his death, Emily acquires this habit and moves away from her companions, "immediately to the chamber, where the remains of her father were laid, and yielded to all the anguish of hopeless grief." Radcliffe's tripartite structure remains intact here with retreat, silence, or dejection brought on by recollection, serving as an anchor. When Emily is captured, she no longer retreats, but paces between the window and back, unable to find respite. Mobility becomes illusory with Radcliffe using the third section of the sentence to block the action proposed by the first section: "It was so, and Emily then stepped timidly out into the gallery, but paused there, uncertain which way she should proceed." Sentences are punctuated by Emily being "unable to follow [trails] farther" and guides "stop[ping] for a moment to trim [a torch]." While these lines may seem, in isolation, to be the 
humorous literary equivalent of having to stop and tie one's shoe, combined they tell an ulterior story. Radcliffe's use of syntax during moments of ordinary travel produces a cyclical morass of unescapable trauma far more terrifying than the big, curtain-pulling reveals.

Radcliffe's use of sensual and perceptive details features a similar level of distance from the reader (Appendix 3.5); whether it be the physical body in need of support, occluded vision, or far away yet distinct sounds, Radcliffe oscillates between concrete possibilities and uncertain conclusions to enchain the reader to a state of half-knowing perception. Sound is textured, imbuing tonal, pathos-rich, musical, and even tactile features. Radcliffe rarely provides simple sounds, but has them marry or replace one another: "When the rattling of the wheels had ceased, music was heard on the air; it was to Emily the voice of Hope." Here, when one distinctive sound halts, another one replaces it before being allegorized by St. Aubert as a Bunyanian Hope. In another instance, we learn how "In a few moments the voice died into air, and the instrument, which had been heard before, sounded in low symphony." One sound quiets and the other rises, leaving the reader suspended between. This layering of sense words extends to the visual, though the bulk of Radcliffe's sensation words focus on sound. These sentences again follow a tripartite pattern where an initial sound is located, a second replaces, joins, or follows it, and then that sound is reclassified metaphorically or silenced. This third part, as Radcliffe writes, becomes a "confirm[ation] of character"; be it a melancholy strain, soft music, or silence, the reader is rarely left wondering what he had heard.

Scenes of facial reading dominate Lusignan's spectrum of perception (Appendix 3.6). 
Lusignan's author relies significantly less on sounds, providing basic, non-lyrical details that rarely comingle. Classification of either the vision's or sound's sentiment often occurs within the sentence's center, while its effect or import comes at the end: "Gentle melancholy tinged her features, and sorrow was mingled in the smile of benevolence, with which she greeted her fellow-sufferers." By relocating the classificatory portion to the sentence's midpoint, Lusignan's author, while losing some metaphorical specificity, allows room for action to be performed in its third part. For example, "Yaratilda soon appeared with her brother; they released us from confinement, and, in profound silence, led towards the shore." Normally, Radcliffe would opt to close the sentence with a profound silence, which probably arose from another sound, whereas Lusignan's author springs us into action. Like the other topics discussed thus far, the faster pace of these more concise sentences could be perceived as a watering down of Radcliffe's original; we hear groans alone rather than the sound that preceded the groan and then a metaphor that complicates or confirms its message. Nevertheless, we are again forced into progress, encountering terror far more quickly. Where we might find rest in a Radcliffean sentence, we are sprung into motion in one of Lusignan's lines.

I encountered minor topics as well, namely the presentation of sentiment and time (Appendix 3.7). The difficulty with delimiting major stylistic trends from these, however, follows a similar pattern to earlier issues. Radcliffe compounds sentiments with seemingly all objects, images, or moments capable of provoking emotion. In one particularly humorous sentence, she succinctly describes this trend: "The chairs, the tables, every article of furniture, so familiar to her in happier times, spoke eloquently to her heart." Lusignan, alternatively, focuses on bodily expressions of feelings. Aside from 
the many scenes of basic countenance reading, the novel's author tends to embody feelings into their character in far more expressive, measurable ways. Lusignan's Emily "was surprised at the degree of indolence she felt, and at her disinclination to dress, and go to the rooms." We should contrast this with Radcliffe, who, when presented with a scene that demands physicalizing, writes "It was of uncommon beauty, and was characterized by an expression of sweetness, shaded with sorrow, and tempered by resignation." The additive quality of Radcliffe's work avoids straightforward description with streaks of sentiment tincturing most descriptions.

While some form for the Greater Radcliffean Sentence arises from these experiments, to emphasize the tripartite mechanics of Radcliffe's work misses the point; even the imitative works that distant reading techniques deem to be the closest stylistically vary in average sentence structure. Yet this section combines methodologies - namely a localized form of distant reading, topic modeling, and primitive formalism - to show how larger thematics take shape: to write the gothic novel after Ann Radcliffe is to introduce the sensing, perceiving, and moving body into the text. The stasis produced by Radcliffe's most ordinary lines, sticky with contemplative noises and restricted movement, metonymically imprisons the reader. As section two will argue, this style is ultimately moved away from as the Minerva Press mode becomes the norm; the Gothic becomes a site of action. Lusignan's kinetic alacrity, its sprints and its stops, become more important to the preservation of the genre.

\section{5: Conclusion.}

Studying the gothic novel without taking larger account of Minerva Press fiction ignores a wealth of developments in syntax that connect the form to its later iterations. As 
these various experiments and methodologies attest, the Minerva Press novel's great achievement comes from cutting ties with sonic complexity, still bodies, and slow perception. While a qualitative close-reading of these texts would undeniably afford more detail about their philosophical and aesthetic evolution, distant reading and stylometric techniques unearth one of the first treasures of these marginalized texts: the depiction of and the relief of momentary pause. The idea of improvement may be subjective - and, indeed, many may find the lexical richness and melody of Radcliffe's prose preferable but we see in Lusignan and other works a clearer, more direct vocabulary for sensation and perception, one that loses in affect what it gains in distance covered. Lusignan lets the readers truly recover, identifying its spectral noises and sights sans complication.

Through these various stylometric procedures, larger questions for the field emerged. If detecting deliberate imitators is all but impossible by modern methodologies, at what point does qualitative, close reading become necessary? For all of the stylometric fireworks this section launches, a rough, primitive kind of formalism coupled with average word counts went the furthest to delimit Udolpho from Lusignan. The Federalist Papers and Shakespeare's folios may be models for stylometric analysis, but messy OCR results and the unavailability of pristine digital editions create an impasse for work in this period. While critics like Jerome McGann have rallied for better electronic editions, the institutional realities of the profession make a digital Tom Jones far more fruitful and relevant than one of Llangloed. Perpetuating the myth of a Radcliffe-authored Lusignan stands to benefit the Minerva Press novel, Gothic studies as a whole, more than debunking it would.

But our questions for the Gothic should extend beyond those of authorship; we do not 
need to discover another Ann Radcliffe novel, but to closely read the works that she inspired from a healthier distance. William Lane's stable of writers, unscrupulous as some of their work was, instrumentally standardized the gothic sentence. As Section 1.3 suggests, it would be better to find several new female gothic figures and study them at their own face value than continue an over-two-century tradition of measuring their literary value by proximity to Udolpho. Moreover, we must do more than make the jump from Udolpho to The Monk to Frankenstein, even the jump to Wordsworth and the Romantics. The Monk may have been the most notorious gothic novel, but a large quantity of literature that became responsible for sustaining the form's reputation diverged from its model. Distant reading may not be a thorough technique, whether by PCA or culling sentences of a particular length from a text, but it's a necessary peek into what these otherwise marginalized texts can provide us. If anything, this section hopes to provide a sneak preview

Whether or not Lusignan was written by Radcliffe, it serves as a worthy case study for how some Minerva texts were able to blend the qualities of Lewis and Radcliffe, forming a distinctive, yet informed successor. We may always prefer the creeping suspense found within even Radcliffe's most ordinary sentences, the highly idiosyncratic style difficult to imitate. When we move into the nineteenth century where the gothic novel is all but extinct, this compressed, more common form is capable of resizing itself into punchy moments and short stories. More importantly, the form's movement into the commonly printed and unprecious paved the way for the gothic story's eventual home in the magazine.

\section{Gifting the Gothic: The Politic of the Early-Victorian Ghost}




\subsection{The Cyclical, Global Gothic Present}

The Gothic's home during the early and mid-Victorian period was the bound anthology and periodical. In both ladies' magazines and gift books, gothic short fiction maintained a steady popularity from the 1790s well into the 1840s in both England and America. Edgar Allan Poe, for instance, first published seven of his short stories in the periodical Godey's Lady Book between 1834 and 1849 and two in gift books. Not all works published in magazines were original; a number were recycled from Minerva Press works, with Franz J. Potter contending that Gothic fragments were even serialized in some magazines (79). Giftbooks, better known as the Annuals, were distributed less frequently, but were also compilations that contained a variety of poetry, short fiction, engravings, essays, sheet music, and political essays. The more high-end versions of the Annuals, like The Keepsake, featured the works of the canonical Romantic poets alongside illustrations of arabesque and sublime architecture by William Finden and John Martin. The Brontë sisters were known to both read these stories and sketch their accompanying plates (Alexander 415). Chapman suggests not only that Elizabeth Barrett Browning read from this transnational print network, but that her epic poem, Aurora Leigh, "was produced as part of the culture of poetry" and owed a debt to "expatriate poetry culture from which it emerged"; in Italy, national and imported versions of the Annuals were circulated by an ex-patriate network (276-277). The mixed bag of major Romantic poets and up-and-coming short fiction writers may seem like sturdy enough pylons to erect and demarcate the early Victorian gothic genre - a sequel to Kilgour's monstrous assemblage that has, this time, left the laboratory and gone international.

Yet, even with the inclusion of well-known poets, the Annuals were not critically 
received any better than Minerva Press novels, but did remain popular for about as long; unlike the serial or even the periodical, the stories and poems published in an annual were not only one offs, but likely to be ignored by critics who mocked the form as "butterfly books, gilded flies, glittering books, agreeable trifles, and tawdry rubbish" (Linley 13). Capable of selling over "fifteen thousand copies within a few months" (Alexander 413), some version of the annual was found in many middle class homes. Yet, beyond their appearance and ubiquity, gift books were radical spaces. Margaret Linley writes that once again "technological innovation and femininity combine in the annuals to exemplify the compatibility...between industrial progress and aesthetic development” (16). The combination of transatlantic and transeuropean circulation globalized the conditions of the Minerva Press-esque narrative, creating a non-hierarchical volume that would contain excerpts of Wordsworth alongside "The Witch of the North."

The Gothic's place in early Victorian literature is in the momentary and ephemeral. Whether it be in the pages of a gift book or periodical, or embedded within an epic poem, the Gothic becomes a style that has to navigate and maintain itself through heteroglossia. With the Annuals being the most widely disseminated form of gothic fiction, transnational audiences were exposed to the form in its most immediate, unsophisticated form, recycled Minerva Press tales and all. This isn't to suggest that the Brontës, Gaskell, or other audiences stopped reading Ann Radcliffe and Horace Walpole, but rather that the genre no longer thrived in four volume lending library knockoffs, but as excerpts, short fiction, and poetry with a pronounced sense of disposability.

Part of its shrinking and ephemerality may also figure into the genre's new purpose for nineteenth-century readers; no longer was it considered a mode that transmogrified 
and mitigated the tensions of the French Revolution, but rather one that "turn[ed] any formation that challenged the nuclear family into a form of degeneracy so hostile to modern selfhood as to negate emphatically its very being" (Armstrong 146). While this approach may work for later gothic works of the period, the form practiced by the Brontës, Gaskell, and Barrett Browning lent itself more to the print network they drew upon. We see in their works the Gothic functioning to unify and rally the oppressed, to weave together and shore a kind of misfit literary family far suppler and more inclusive than the nuclear.

This section, contrary to Armstrong, suggests that early Victorian gothic work used relatively tight confines to address threats to female authorship posed by the spectral. Writing gothically in the early Victorian period presented a double bind where a movement away from the Gothic was as necessary to redefine female authorship as working within the form was. Both Gaskell and Barrett Browning use their gothic moments to subvert established conceptions of family. This includes providing an overly intricate patriarchal family tree where only the matrilineal becomes discernible and depicting the complex generic implications a concurrently terrible and beautiful mother's portrait holds.

Gaskell and Barrett Browning employ highly crafted gothic syntax with the kind of political rhythm Caroline Levine writes is "capable itself of exerting or transmitting power" (74). Gaskell's oral narrator in "The Old Nurse's Story" mimics and incorporates the syntactical styles of the story's two other story tellers, moving power away from the patriarchal matrix presented in its first paragraph. We see in Aurora Leigh the mechanism of generic expectation exploited to produce compounded moments of fixedness; we 
pause not only at deathly faces, but at the heightened, exaggerated version of the Gothic she uses in seemingly inappropriate situations. This high voltage intensity isolates the mode in a manner reconciled only through subsequent hybridization; Barrett Browning relieves the vulgarity of the gothic narrative through placing it near other forms, such as the classical. This demonstrates a means not only of stretching the affordances of the Gothic, but avoiding the sort of critical pigeonholing a longer indulgence with the mode would entail. Both authors demonstrate how one can keep the Gothic integral and politically vivifying to female authorship amid the increasing globalized, cosmopolitan network of print culture.

\section{2: Runs in the Family: Elizabeth Gaskell's The Old Nurse's Story and Matrilineal Syntax}

The introductory paragraphs of Gaskell's “The Old Nurse's Story” attempt to compress a dense, slippery familial network into a logjam of proper names. For a story shorter than a single chapter of The Mysteries of Udolpho, Gaskell's work rushes through a whole novel's familial lineage with an ear to a younger, perhaps less attentive, audience. After its second sentence hazards one hundred and fourteen words split by twelve commas, Hester, the nursemaid, course-corrects: "I see you don't care so much for this part of my story, as for what you think is to come, so I'll tell you at once." Telling it at once does more harm than good, traditionally speaking. Gaskell's narrator speeds through about six other characters from two sides of the family and nearly as many place names. As Jack Voller notes, disjunctures in this family lineage occur with Hester 
presenting genealogical impossibilities such as Grace Furnivall and the present day Lord Furnivall being cousins. We end up with three Lord Furnivall's by the tale's end, three different Miss Furnivalls, and several other characters who are renamed; Miss Rosamond suffers the worst with Hester bestowing over a dozen pet names on her.

It's difficult to suggest, however, that readers themselves were expected to fully understand this dense ancestral web, or that Gaskell herself intended comprehension. In this section, I seek to draw an alternative conclusion from Voller, suggesting that Gaskell's third Furnivall was not an editorial mistake, but rather a performance of the difficulty associated with condensing the gothic narrative wholesale for a new readership. While early criticism presented this short story as the missing link between Wuthering Heights and The Turn of the Screw within the gothic lineage, deeming Hester an unreliable narrator because of a handful of factual inaccuracies ignores the necessities that both orality and compression impose. Amid the flurry of data, however, Gaskell's narrator oft reminds us that "Miss Rosamond" is the mother of Hester's audience. Hester reports of a "Miss Rosamond, (that was the baby who is now your mother)" and "your mother, little Miss Rosamond" only a sentence apart. In her haste and effort to compress, Hester unequally doles her comprehensive yet flimsy resuscitation of the familial, privileging motherhood over the excess. Gaskell's short story enacts a multi-generational form of stylometric motherhood where Hester incorporates the oral idiosyncrasies of the story's two other speakers, Miss Rosamond and Dorothy. It doesn't seek to clearly elucidate a traditional family, but rather to create and foster a literary one by employing gothic, spectral agents as lexical binders.

Published in 1852's Christmas Edition of Household Words, Gaskell's gothic short 
story is notable for being eagerly commissioned by Dickens himself; from its conception, it was a work of intense literary collaboration with great excitement behind it. In an 1851 letter, Dickens expressed a mutual fascination with "Ghost-stories, illustrating particular states of mind and processes of the imagination." What elevated these these stories over others was "the manner of relating them." The fascination with ghost stories wasn't entirely their content or psychological depths, but how they were told. Gaskell had already published gothic short stories in Household Words since 1851, but none with the same anticipation as this, given its place in the Christmas issue, a space notable for its focus on British anxieties regarding emigration. Ludlow and Styler write that these stories negotiate "the relationship between domestic spaces (of home and nation) and the exterior locations of marketplace and colony" (8). This inside-outside dichotomy, in Gaskell's case, was metonymized in the navigation of interior states with external realities. Finding strains of psychological distress in Hester is not especially difficult; she obsesses over Miss Rosamond after her mother's death, anticipates spectral visitations before they arise, and often mimics Rosamond's juvenile activities such as playing hide and go seek simply because the child enjoys them. While a psychoanalytic approach may seem germane - instances of doubling and repression abound - "The Old Nurse's Story" avoids these approaches by focusing on the collective voice rather than the individual psyche. Dickens poses the work as a collaboration with two proposed alternative endings joining the original, part of an ongoing conversation rather than a symbolic whole. We must take a page from Dickens and focus not only on the balance between internal and external states, but the manner in which a story is transmitted through multiple authors. While David Galef suggests that Gaskell's tale adds a highly Freudian “symbolic 
complexity" to the Gothic, it goes against the text's otherwise slavish devotion to material realism. Despite being a ghost story, very little detail, be it ancestral or architectural, is occluded from the reader enough to suggest deep symbolism. Gaskell's narrator, for instance, spends multiple paragraphs building Furnivall Manor, including details about a pair of asymmetrical doors in the grand hall, passage ways, and rooms. Architectural realism covers a large portion the story's beginning, following Josie Billington's claim about Gaskell's novel-length works “faithfully rendering the dense complexity of life's matter" (9). This section seeks instead to suggest that the short story deals with a larger, formal kind of literary mothering: how does one write effectively in a form that was all but orphaned to the strictures of realism and changing audience tastes? What did Gaskell cull and shore from the Radcliffe school while maintaining realism? The answer I put forward is that oral transmission offers a new lexical makeup to tell the gothic story without sacrificing many aesthetic features.

Radcliffe may only be one of the authors to look at, though; the physical form of Gaskell's work bore a closer resemblance to the Minerva texts than to long form novels and many of their techniques, including the use of moments of clear perception. We may see resemblances in format, too. Dickens wrote to Gaskell in 1850 with the idea of starting a "cheap" weekly journal where "no writer's name...[would] be used." While Dickens originally envisioned the periodical dealing mostly with social issues, raising the lower higher, Household Words featured a number of ghost stories composed by Gaskell pertaining to mental phenomena. These stories, too, were of inconsistent length and often hastily written (2). Like the eighteenth-century lending library, Household Words aspired to improve the availability of works that would be approachable to the lower classes. 
While Gaskell never wrote a full Victorian gothic novel, her contributions were decidedly Minervan in that they existed in the common, easily disseminated, and anonymous text.

The canonical "female gothic" catchall associated with Udolpho's author fails to capture the immediacy and experimental quality of Gaskell's work unless we begin to include Minerva works. The poetry is replaced by a slippery oral recounting; the Radcliffean theme of imprisonment, here, is radically inverted when the old Lord Furnivall casts his daughter into the cold, unforgiving wilderness with her child rather than confining her indoors. As Angus Easson notes, one of Gaskell's more comical resistances to gothic expectations comes with Hester's reaction to the pipe organ music; upon hearing a spectral organ play in the distance, she nonchalantly reports "I thought it rather pleasant to have the grand music rolling about the house, [no matter]... who be the player" (42). The closest Gaskell's work comes to Udolpho is in its use of oral storytelling. Towards the end of the novel, Radcliffe has a character named Ludovico read aloud a twelfth-century work entitled "The Provencal Tale." The text interrupts this tale by inserting bracketed sections that describe the chamber, its noises, and its occupants as Ludovico senses them. While "The Provencal Tale," according to the narrator, was of "simple structure and exhibited nothing of magnificent machinery" (552), it is "tinctured" by these bracketed sections; what we expect to be a formulaic spooky story intentionally acquires a new level of horror through its performance. When the story's Baron thinks of his warm chamber and its "blaze of wood" (555), Ludovico "paused for a moment, and, looking at his own fire, gave it a brightening stir." Similarly, when the story's Baron was about to confess his secret and "utter these words: _-", Ludovico lays down his book "for he thought he heard a voice in the chamber" (556). 
Two of Ludovico's three interruptions appear to be directly motivated from the text he reads; when the Baron contemplates his fire, Ludovico considers his own; when the Baron fearfully expects to hear a voice, Ludovico claims he hears one as well. Gaskell's work, too, hearkens towards orality with Hester often directly addressing her audience and then embedding other tertiary, yet distinctive oral performances by Miss Rosamond and Dorothy.

Rosamond and Dorothy's tales, as recounted by Hester, contain an eclectic mix of quoted sections that are highly jarring in both their syntactical difference and similarities. Just as Hester imitates Rosamond's activities, she comes dangerously close, when recounting the latter's story, to copying her manner of speaking. Gaskell writes:

[Miss Rosamond] said, that she had fancied that she should like to go to Dorothy, for that both the old ladies were asleep, and it was very dull in the drawing-room; and that, as she was going through the west lobby, she saw the snow through the high window falling - falling - soft and steady; but she wanted to see it lying pretty and white on the ground; so she made her way into the great hall; and then, going to the window, she saw it bright and soft upon the drive; but while she stood there, she saw a little girl, not as old as she was, 'but so pretty,' said my darling, 'and this little girl beckoned to me to come out; and oh, she was so pretty and so sweet, I could not choose but go.' And then this other little girl had taken her by the hand, and side by side the two had gone round the east corner. (44, emphasis added).

Hester almost eerily adopts Rosamond's soft and sweet vocabulary when recounting portions of her story. In the text, the words pretty, soft, and sweet have been used only by Hester to describe Miss Rosamond to her children: she is a "pretty, young lady", a "pretty young mistress", and a "bright and pretty pet" in the first few paragraphs (35-36).

Rosamond's language for describing Maude's spectral daughter mirrors how Hester herself begins the tale. This begs an important question not yet posed by critics: where is Miss Rosamond now? Though Hester recounts this tale to Rosamond's children, the 
similarity in language and syntax shows that, once more, our narrator has absorbed and become the absent mother figure. After the shepherd returns Rosamond from outside, Hester calls her "my little lady - my lamb - my queen - my darling" (45). The strange disjuncture between queen and little lady complicates the relationship between the two. Criticism has all but ignored Hester's infatuation with Rosamond, but I argue that it's something in how Rosamond tells her story that produces the attraction.

Much as in Ludovico's tale, Hester's performance of Rosamond's language and syntax, describing her almost identically to Maude's daughter, produces its own cyclical form of gothic trauma divorced from the patriarchal realm. Though we could just pose this as another instance of Hester "lik[ing] to do whatever [Rosamond] did" (48), she also copies certain idiosyncratic qualities of Rosamond's speech. During one of the few instances we get a quotation from Rosamond, we see a particular quirk in her speech patterns where words are repeated twice. She says "I can't help it, dear, dear Hester...she held my hand fast and tight in her little one, and it was very, very cold" (47). This childlike idiosyncrasy is parroted by Hester when she described the snow as "falling - falling" when recounting Rosamond's story. The young character's favorite repetitions of words, however, is saying the name of her nursemaid twice in quick succession: "'Oh Hester! Hester!' cried Miss Rosamond. 'It's the lady! the lady below the holly-trees; and my little girl is with her. Hester! Hester!"” (55) In all of the dialogue Gaskell includes from Rosamond, she always includes the name Hester at least once, seemingly unable to speak unless the tie to her guardian can be made. We might approach this as a testament to the strong bond formed between the nursemaid and her ward, but Gaskell presents something more telekinetic and connected. While Rosamond eats, for instance, Hester stands behind 
her for the entirety of the meal; afterwards, she goes to kitchen to eat her meal, yet knows that Rosamond "would play about in a corner of the great drawing-room, as still as any mouse." While Galef poses Hester as the "just right" maternal figure for Rosamond, this ignores the latter's stifled desire for an age-appropriate playmate and a mother figure in Maude Furnivall's ghost. If we approach the more enigmatic, peculiar moments of Hester's narration, it's clear that a far deeper connection between the two, well past adoptive-mother and daughter, exists.

Dorothy's tale provides the cipher as Hester also copies the former's syntax almost entirely; "The Old Nurse's Tale" is about the additive, nearly polyphonic quality that the gothic narrator can achieve. Like the young Jane Eyre, Hester's tale is one of learning to tell her story. Whether it be by copying Rosamond's peculiarities, adjusting her narrative for Rosamond's children, or lifting sentence structure from Dorothy, Hester culls from a multigenerational line of storytellers to create the tale we read. Dorothy's last paragraph, for instance, features the line:

"One fearful night, just after the New Year had come in, when the snow was lying thick and deep and the flakes were still falling - fast enough to blind any one who might be out and abroad - there was a great and violent noise heard" (52).

Meanwhile the spectral episode with Lord Furnivall narrated by Hester starts:

"One night - just after New Year's Day had come at last, and the long winter had taken a turn, as I hoped - I heard the west drawing-room bell ring three times, which was the signal for me" (53).

The doubling that occurs here is, first and foremost, syntactic; this is not just another New Year's day, but one where the very architecture of the second sentence recalls the first. Whereas Dorothy's line continues with a component analysis of a cacophony - "the the old lord's voice above all, cursing and swearing awfully... and the cries of a little 
child... and the proud defiance of a fierce woman" - Hester springs into action, knowing the trio of sounds well enough. Yet, she retains Dorothy's penchant for dashes, writing "I would not leave Miss Rosamond alone, for all she was asleep - for the old lord had been playing wilder than ever - and I feared lest my darling should waken to hear" (53). The kinetic energy relayed in Dorothy's dash remains in Hester's portion.

While Dickens had originally wanted only Rosamond to see Miss Grace Furnivall become a spirit, joining her sister and father, at the novel's close, Gaskell's insistence that all characters witness the event gains new importance in this reading. Throughout the story, the veracity of the tertiary narratives is called into question: Rosamond sobs and claims that she's “telling it true” (47) after being reprimanded by Hester, while Dorothy's story "might not be true, or it might, [it was only] what she had been told" (52). Telling, transmitting, and believing these narratives enables the mistakes of the past to be avoided; by listening to both Rosamond and Dorothy's stories, incorporating their details, Hester and her beloved survive the patriarchal threat that beckons for another woman's early death. We might also consider the voices Hester does include, namely those of a young child and servant. Several scholars have already noted the connection between this short story and Wordsworth's Lyrical Ballads; the child's ability to recognize the dead well before the older and more suspicious characters recalls the cottage girl from "We are Seven." The young Rosamond's position in the narrative as unimpeachable and full of sensibility is set from the get-go: Hester tells her audience that "there never was such a baby before or since...for sweet, winning ways, you've none of you come up to your mother" (35). Her empathy for the young girl and mother exceeds Hester's own and she's the first to actually see the ghost. More importantly, however, is Dorothy's crucial role in 
the text. Gaskell not only gives the servant a voice, but makes her storytelling vivid and integral.

The Furnivall family tree and other notable omissions like who the audience's father/Rosamond's husband is become less important in this reading of "The Old Nurse's Story." Gaskell rushes through the convoluted, patriarchal lineage of the Furnivalls at the beginning because the new family, modeling instead the family formed by those who are normally voiceless telling stories and building on one another's styles,. Miss Furnivall's failure to join this new lineage, ultimately, spectralizes her as she rejoins her father and sister. If we read into the short story's ending a bit further, Miss Furnivall's youth spent in a patriarchal gothic plot could not be undone in age; her unwillingness to confess the story of her sister, to engage in the oral, polyphonic tradition around her, leaves her the home's resident spirit. Gaskell seems, in both Household Words and the form of the ghost story, to extend her egalitarian politics; through the assemblage of the disparate and the transgenerational, the recited story is capable of overthrowing a lingering, male ghost. Miss Rosamond's exceptionality stands not only in her idiosyncratic voice, but her willingness to share her experiences without restraint. Yet to privilege her to the vision, as Dickens would want, would extinguish the communal effort and leave the story in the realm of the supernatural. For Gaskell, both in her publication decisions and in her story, the ghostly figure must be seen by all who intend to repeat and retell its sighting.

\section{3: Facing Death: Politicized Phrenology in Elizabeth Barrett Browning's Aurora}

\section{Leigh}


Elizabeth Barrett Browning's epic poem, Aurora Leigh, bears little formal or thematic resemblance to a Minerva Press novel, let alone those of Ann Radcliffe; while Gaskell's work concurrently embraced and struggled with the gothic blueprint, Barrett Browning worked only in tiny, yet alarming gothic bursts. Classified most recently by Herbert F. Tucker as a spasmodic poem, Aurora Leigh recounts the tense relationship between the titular character and her cousin Romney through a bildungsroman turned diaristic narrative. The broader thematics of the Gothic can, of course, be used to make a tenuous connection between Barrett Browning's poem and the genre; its exiled, orphaned protagonist, themes of incest and rape, and prevalence of premature burial metaphors tap the gothic vein. Recently, Barbara Barrow has made the case that Aurora Leigh's emphasis on the body “fuels the poem's internal dismissal of women's poetry" (243), opting instead to privilege classical elements like the epic form. The poem's bodily insecurity, Barrow argues, promotes a search for a kind of disembodied poetics that prevents essentializing.

Yet, Barrett Browning's attention to the body, namely deathly faces, aligns her work instead with the women's gothic novel in a more substantial, phrenologically minded-way; she critiques and politicizes more than dismisses. Barrow's attention to epic form misses the other, non-poetic communities Barrett Browning's work engages with. When we encounter boilerplate gothic moments in Aurora Leigh, sentences rich with many of the Minerva Press novel's body-centric features, Barrett Browning punctuates the form with the face of dead or dying women. The Gothic dialectically alternates between being a style inseparable from the moribund female body and a necessary memento mori that calls to hybridize form: 'to gothicize a 'high' and 'masculine' form 
like epic...means that one must transgress against the very assumptions that seek to keep gender and class boundaries clear and distinct" (Gamer 12). While Dolores Rosenblum suggests that the majority of female faces in the text serve as gateways into Romantic vision (321), Barrett Browning notably borrows from a few decades earlier as well as contemporaneous annuals, to feminize the epic. In addition to Marjorie Stone's work on Aurora Leigh's subversion and inversion of the male poet's preferred genres, this section seeks to identify how Barrett Browning worked with, by mostly working against, the feminine features of the Gothic novel to politicize what remained vivifying in a decaying visage.

This is not to to delimit Barrett Browning's usage of gothic motifs to only the political; the author doesn't just cull the form's worst features, but as Stone suggests, Barrett Browning shows a "considerable ability to construct a suspenseful story" (116). We should parse the moments that produce genuine suspense from those that overtly rely on gothic mainstays; Barrett Browning doesn’t necessarily parody, but over-accentuates and flourishes, imposing the style on her readers. For instance, immediately before Aurora Leigh's aunt passes away, she writes that:

Then suddenly, a single ghastly shriek Tore upward from the bottom of the house. Like one who wakens in a grave and shrieks, The still house seemed to shriek itself alive, And shudder through its passages and stairs With slam of doors and clash of bells. (911-916)

Hardly subtle, Barrett Browning compounds this moment by tripling the screaming agents: we have the original shriek, the shriek of one "who wakens in a grave," and the still house, seeming "to shriek itself alive." A rhythm section of slammed doors, clashed bells, and shudders through passages join this harmonized trio in creating a cacophony on 
the page. It is in these moments that we see, rather than an appeal to readerly suspense, a form of generic self-awareness meant to signal the reader. This kind of exaggerated preamble occurs earlier when Aurora, before discussing her mother's portrait on the wall, recounts how:

Old Assunta [used] to make up the fire, Crossing herself whene'er a sudden flame Which lightened from the firewood, made alive That picture of my mother on the wall. (125-129)

The combination of the flame's vivifying qualities and Assunta's superstitious, religious crossing establish a gothic gloss that coats the subsequent scene; Barrett Browning has characters perform a kind of pantomime, informed by half a century of recycled gothic fiction.

Another call to attention follows this portrait scene where Aurora first establishes the connection between gothicized women's faces and death. By playing on the convention of the spectral relative's face immortalized in a portrait, Barrett Browning introduces a motif where the meditation on a face ends in death unless it, too, manages to move past a single generic description. Aurora goes into the specifics of the painting's creation, writing that "The painter drew it after she was dead/ And when the face was finished, throat and hands" (1.130-131). By capturing the face first, the painter recorded a strange effect that altered the visage's appearance (137-138) depending on the context. While this trope was popular in nearly all gothic fiction, it's important to note that Aurora varies her experience with the portrait, presenting it as entirely dependent on circumstance: "I, a little child, would crouch/ For hours upon the floor with knees drawn up/ And gaze across them, half in terror, half/ In adoration” (138-140). Leigh's complicated oscillation between fearing and adoring the portrait's "supernatural" beauty 
that breaks "out of bounds" (141-144) represents Barrett Browning's strained relationship with this device. Reducing it to a "grotesque collage of death and sexuality" (Rosenblum 328) avoids its multiplicity.

When Aurora stares specifically at her mother's face, she witnesses a variety of generic capabilities well beyond the Gothic alone, demonstrating how the genre can be expanded through the melding and inclusion of other works. Aurora recounts how

For hours I sat and stared...

In years, I mixed, confused, unconsciously, Whatever I last read or heard or dreamed, Abhorrent, admirable, beautiful, Pathetical, or ghastly, or grotesque, With still that face... which did not therefore change, But kept the mystic level of all forms, Hates, fears, and admirations, was by turns Ghost, fiend, and angel, fair which, and sprite ...A still medusa with mild milky brows, All curdled and clothed upon with snakes Whose slime falls fast as sweat will. (40-59)

By joining the ghost and fiend figure with angel and medusa in her description, Barrett Browning denies purely gothic associations with this scene. Aurora Leigh's mother is vivified by all of these qualities, good or bad, depending on the experiential heteroglossia Aurora enters the space with. The Gothic is redeemed when it goes past the affordances of the abhorrent, ghastly, and grotesque; a style that survives when it hybridizes with other genres. As Tucker writes, the "plot of the poem" is the positing, "then overcoming, [of] a primary schism between arbitrary regulation and victorious sovereign impulse" (379). We see this on a more local level with the Gothic; the form must be established through the repetition of tropes like moving portraiture, challenged through the sporadic burst of inherent beauty, and then resolved when fiend and angel stand side by side.

Nevertheless, Aurora Leigh deliberately contains moments where the bounds 
remain unbroken and the tyranny of form becomes mortal. Barrett Browning condenses the Gothic to employ it as a didactic warning against gendered literary monocultures. Following the trio of shrieks earlier, Aurora Leigh springs out of bed and is confronted at her door by "A white face - shivering, ineffectual lips" (919). The face's "ghost[ly]" (921) appearance and inability to produce utterances both pays homage to and critiques the gothic form; Lady Leigh's maid Susan suffers from a deathly condition simply by being a part of the scene. The role informs her phrenology. Aurora's motion, too is animated by the scene where she is drawn by the point "Of a fiery finger through the uneven dark, /... [going] with reeling footsteps down the stair, / Nor asked a question" (921-924). Leigh's loss of agency, the fiery finger, and her inability to question the scene constrict the reader to the strictures of the Gothic. Even without the domineering patriarch, form itself demands her compliance.

Her aunt's reveal continues this trend, with another pallid face bringing about the physicalization of a constrictive generic framework. Yet, Barrett Browning discovers a method for subverting the expectations of form. Leigh's aunt is found "bolt upright" (1.925) in her chair, immobilized and dead. Barrett Browning plays a kind of a practical joke on the reader when we see the aunt's face; Leigh recounts how "The dumb derision of that gray, peaked face/ Concluded something grave against the sun, / Which filled the chamber with its July burst/ When Susan drew the curtains" (926-930). By having this deathly face and scene occur in the bright July sunshine, Barrett Browning denies the reader's expectations for the Gothic. All is visible. The gray, mortalized face mocks its surroundings, acting as a kind of obstinate, out of place relic of an earlier form. This scene challenges generic frameworks, showing how the provision of one small detail, a 
July sun, can change a grave visage into a comically out of place sight. Browning's dual use of the word grave, its call to seriousness but also a marker of death, continue this tightrope act between play and the political.

She continues to haphazardly deploy the Gothic during Romney’s wedding, juxtaposing England's starved and sick working poor - the true horror - with the decaying aristocracy who pale and become ghostly at the prospect of Leigh's marriage to Marian Earle. While this representation separates genuine mortality from the gothic tropes associated with death and the spectral, employing the form with comic levels of irony calls our attention to it; Leigh is performing the Gothic to address social issues. Judging by the crowd, we'd "suppose/ A finished generation, dead of plague, / Swept outward from their graves into the sun" (546-549). Without restraint, Leigh continues to describe this crowd's movement as the oozing of "a dark slow stream, like blood' (553-554). Our inability to empathize with these scenes of supposed terror alerts us to the aristocracy's overreaction; the Gothic flattens these characters into Dickensian dissenters. Barrett Browning, however, directs readers to these individuals' faces - faces that are "pale with fear" (556) and "hide in cellars" (573); faces that appeared "as if [they]... had stirred up hell” (588). By metonymizing this gothic scene of oozing blood and plagued bodies into pale faces, Barrett Browning again shows the form to be a reductive, totalizing one, but also one capable of revealing latent hypocrisy. Its egalitarian ability to highlight flaws in the aristocracy through its overdramatic language and syntactic conventions performs the kind of social leveling Romney’s attempted marriage to Marian Erle could never achieve.

Leigh exceeds this mode of heavy-handed, dense gothicization as we move later into the text, although pallid faces and deathly scenes remain in somewhat tighter 
portions. If we put this text in conversation with the likes of Jane Eyre, worthwhile

parallels emerge. While the young Jane at Lowood has no issue turning Brocklehurst into a towering column or adding staircases and commas during dramatic scenes, the genre seems less prevalent in her adulthood. Part of the women's bildungsroman tradition involves the adjustment of storytelling, whether that means balance or more measured speech. Still, despite the form's scarcity in later Books, we shouldn't entirely dismiss Aurora's earlier usage as necessary, writerly growing pains. Late in the novel, Romney Leigh uses the gothic form to little effect, describing his experience while Leigh Hall is burned. He recounts:

The echoing galleries, half a half-mile long, And all the various stairs that took you up And took you down, and took you round about

Upon their slippery darkness, recollect, All helping to keep up one blazing jest; The flames through all the casements pushing forth, Like red-hot devils crinkled into snakes, All signifying, -'Look you, Romney Leigh, 'We save the people from your saving, here, 'Yet so as by fire! we make a pretty show 'Besides, -and that's the best you've ever done.' (970-980)

The lack of political force to Romney's employment of the form, his "all signifying" and "symbolic of my life" (8.1034) conclusions, pale in comparison to Aurora's socially motivated usage. Romney accentuates the details of his suffering, yet believes that the story's import goes no further than his personal life. Stuck in just a bildungsroman mindset, all adversity propels Romney's progressive narrative. Moreover, the replacement of facial details with an inventory of Leigh Hall's building materials and rooms delimits the scope of his story to lifeless objects. While the Gothic animates and constricts all present females, be it during Aunt Leigh's death or the gooey, pallid crowd 
at Romney's wedding, the form possesses a revelatory, consequential danger. Romney's gothic lacks the fear of fixedness; of a face remaining constrained to the gothic form. While he is able to invent his own symbols and conclusions, Romney's gothic perils arrested development.

While Aurora Leigh manages to encompass many genres, its small, but meaningful politicization of the Gothic stands out. By employing the style's language and tropes in spasmodic pulses, Barrett Browning finds a new source of terror relevant to the English Question: fixedness. Embodying this terror squarely on the faces of her female characters, Browning finds real utility in a style she seems almost to parody. The overblown gothic moments - the shrieks and the darkness - ironically distance the reader enough to notice its peculiarity. Yet, like Aurora's mother's portrait, the relatively terrible visage mutates when we return to it; what functioned as a fearful prop oscillates to become beautiful - a morose memento mori. We cannot, however, risk an analysis like Romney's; to say that Barrett Browning's employment of the Gothic is all political, all jarring, or all about the risk of fixedness ignores what surrounds these moments. Barrows writes that the poem's "bolder feminist contribution lies in its willingness to suspend and question the relation between language, gender, and the body" (258). Aurora Leigh's bite-sized gothic pulses alarm in their eccentricity, but Barrett Browning employs this suspension to produce contemplations in the reader. We are to wonder how a portrait could be generically hybridized, how a gothic scene could end with a woman starring at a July sun, and how to disembody the aristocracy into a kind of languid sludge. Aurora Leigh uses the gothic to provide a space for radical reimagining. 


\section{Conclusion: A Haunted House}

Can the suspension in a gothic line become a transgenerational network? Woolf begins "A Haunted House" writing, "Whatever hour you woke there was a door shutting. From room to room they went, hand in hand, lifting here, opening there, making sure - a ghostly couple" (3). In these lines alone, strains of Radcliffe, Lusignan's author, Barrett

Browning, and Gaskell emerge. Woolf begins familiarly with an indefinite time, followed by a rousing moment, and then a distant sound. Room to room, hand in hand, words double as an investigation is underway. Disparate parts are moved - a lifting, and opening, and a confirmation - until we pause at the ghostly couple. But, as the home's current residents announce, it was not the ghosts that woke them. As the dead and living alternate speaking, the barrier between the two disappears until, together, a lost treasure is recovered. One questions, "the pulse stopped short. Oh, was that the buried treasure?" (4)

Yes, the Gothic's ability to still, pause, and recover is indeed a treasure buried within a syntactic lineage; one that Radcliffe utilizes and one that Woolf, with deftness, promulgates in her two-and-a-half-page short story. In these pauses, Woolf encompasses the tradition: “Oh, no. 'They're looking for it; they're drawing the curtain,' one might say, and so read on a page or two. 'Now they've found it,' one would be certain, stopping the pencil on the margin" (3). The short story's voice imagines the mechanics of reading what appears to be a gothic novel; one reads a text with a climactic, curtain pulling reveal (made famous by Udolpho), unable to put the text down until finding it. The two-page interval between "drawing the curtain" and "finding it" serves as a double for the short story's own frame - the search for the buried treasure, the "light in the heart" (5); much 
like "The Old Nurse's Story" and the Ludovico episode of Udolpho, the story is retold and repeated by the listener. The reader, moreover, triply imitates this pause by stopping his pencil, recognizing and studying the technique sans marginalia. Woolf's text is haunted and inhabited indeed by the styles and gestures of the home that is female gothic authorship.

No methodology lends itself to analyzing the Gothic entirely because its style imbues it with an unmatched formlessness and versatility; we need cultural historicism, new formalism, and distant reading to even begin to plumb the depths. My first chapter details how the genre's unique printing conditions allowed the style to become essentialized, mass-produced, and lucrative within a decade of its rise. The dialectic between Radcliffe's Udolpho and William Lane's publications helped the Gothic become ubiquitous not only in fiction, but also in nonfiction forms like travel narratives and histories. When we observe the most successful imitators, like Lusignan, pacing becomes the ultimate distinguisher; Radcliffe uses her moments of pause speciously, tweaking and weighing down lines that promise a single sound or action. We might consider the Minerva Press novel's process of streamlining essential to the growth and continuity of the genre; when we think about the decline of the Georgian gothic novel and the more stable popularity of anthologized and periodical forms, the trimming of Radcliffe's decadent syntactic essence was crucial to its continuance. The simple respite offered by these texts permitted serialization, truncation, and periodic recycling.

Gaskell and Barrett Browning politicize these well-worn lines, deploying the gothic sentence to accumulate disparate voices and alert through theatrical physicality. The style's recognizability, its surface ubiquity, allowed works to engage with a transatlantic 
reading audience across several languages. While both Gaskell and Barrett Browning jettison most of the style's aesthetics and trappings, they hone and innovate methods of delay. We may not have Aurora slowly approach a shifting portrait or Hester spend pages investigating the locked east wing of Furnivall manor, but both authors recreate the effect through syntactic devices like heteroglossia and word repetition. By embedding this pause in the lines themselves, both authors perform gothic suspension in a manner that no contemporary form of distant reading could decode.

Woolf's short story epitomizes this conundrum: the Gothic occurs in such dense metatextual levels that it evades mono-methodological approaches. When we close read Woolf's haunted house, shades of women writers pass. We see Barrett Browning in the wild beams of moonlight that "stain the faces bent; the faces pondering; the faces that search the sleepers and seek their hidden joy" (Woolf 5); we see the shade of Gaskell in the repetitions of the words "safe, safe, safe" by both the living and the dead; we find the heart of Radcliffe in the line "Nearer they come; cease at the doorway" (Woolf 4). The Gothic is "here," "here too," "upstairs," and "in the garden" simultaneously (Woolf 3). As critics, we must trim not one, but many torches before embarking further. The locked abbey wings of periodization, the limits of method, occlude our insight. We must move from the monster metaphor to the haunted home reproduced, recycled, and circulated globally. 


\section{Works Cited}

Alexander, Christine. "'That Kingdom of Gloom": Charlotte Bronte, the Annuals, and the Gothic." Nineteenth-Century Literature 47.4 (1993): 409-36. Web.

Ardanuy, Mariona Coll, and Caroline Sporleder. "Structure-based Clustering of Novels." Proceedings of the 3rd Workshop on Computational Linguistics for Literature (CLFL) (2014): n. pag. Web. 10 Apr. 2016.

Armstrong, Nancy. How Novels Think: The Limits of Individualism from 1719-1900. New York: Columbia UP, 2005. Print.

Barrow, Barbara. "Gender, Language, and the Politics of Disembodiment in Aurora Leigh." Victorian Poetry 53.3 (2015): 243-62. Web.

Billington, Josie. Faithful Realism: Elizabeth Gaskell and Leo Tolstoy: A Comparative Study. Lewisburg: Bucknell UP, 2002. Print.

Blakey, Dorothy. The Minerva Press, 1790-1820. London: Oxford UP, 1920. Print.

"Bonhams: Lot 207." : RADCLIFFE (MARY ANN)] Radzivil. A Romance. Translated from the Russ of the Celebrated M. Wocklow, 3 Vol. N.p., n.d. Web. 11 Apr. 2016. Brennan, Michael, Sadia Afroz, and Rachel Greenstadt. "Adversarial Stylometry." $A C M$ Transactions on Information and System Security TISSEC ACM Trans. Inf. Syst. Secur. 15.3 (2012): 1-22. Web.

The British Critic. Vol. 10. London: F.C. Rivington, 1798. Google Books. Web. 10 Apr. 2016.

Browning, Elizabeth Barrett, and Kerry McSweeney. Aurora Leigh. Oxford: Oxford UP, 2008. Print. 
Buckley, Matthew. "Introduction." Modern Drama 55.4 (2012): 429-36. Academic Search Premier [EBSCO]. Web. 11 Apr. 2016.

Burrows, J. "'Delta': A Measure of Stylistic Difference and a Guide to Likely Authorship." Literary and Linguistic Computing 17.3 (2002): 267-87. Web.

Burrows, J. "Who Wrote Shamela? Verifying the Authorship of a Parodic Text." Literary and Linguistic Computing 20.4 (2005): 437-50. Web. 11 Apr. 2016.

Chapman, Alison. "Poetry, Network, Nation: Elizabeth Barrett Browning and Expatriate Women's Poetry." Victorian Studies 55.2 (2013): 275. Web. 15 Apr. 2016.

Dames, Nicholas. The Physiology of the Novel: Reading, Neural Science, and the Form of Victorian Fiction. Oxford: Oxford UP, 2007. Print.

Duncan, Ian. Modern Romance and Transformations of the Novel: The Gothic, Scott, Dickens. Cambridge: Cambridge UP, 1992. Print.

Eder, Maciej. "Mind Your Corpus: Systematic Errors in Authorship Attribution." Digital Humanities 2012. N.p., n.d. Web. 11 Apr. 2016.

Flood, Alison. "Gothic Fiction Pioneer Ann Radcliffe May Have Been Inspired by Mother-in-law." The Guardian. Guardian News and Media, 30 Jan. 2014. Web. 14 Apr. 2016.

Galef, David. "'What Is Done in Youth': Sibling Rivalry in Elizabeth Gaskell's 'The Old Nurse's Story'" Gothic Studies Gothic Stud 16.2 (2014): 52-65. Web.

Gamer, Michael. Romanticism and the Gothic: Genre, Reception, and Canon Formation. Cambridge: Cambridge UP, 2006. Print.

Gaskell, Elizabeth Cleghorn, and Angus Easson. Cousin Phillis and Other Tales. Oxford: Oxford UP, 1981. Print. 
Howard, Jacqueline. Lusignan: Or, the Abbaye of La Trappe. Richmond (Va.): Valancourt, 2015. Print.

James, Henry, Deborah Esch, and Jonathan Warren. The Turn of the Screw: Authoritative Text, Contexts, Criticism. New York: W.W. Norton, 1999. Print.

Kilgour, Maggie. The Rise of the Gothic Novel. London: Routledge, 1995. Print.

Levine, Caroline. Forms. Princeton: Princeton UP., 2015. Print.

Linley, Margaret. "The Early Victorian Annual (1822-1857)." Victorian Review 35.1 (2009): 13-19. Web. 15 Apr. 2016.

Ludlow, Elizabeth, and Rebecca Styler. "Elizabeth Gaskell and the Short Story." The Gaskell Journal 29 (2015): 1-22. Web.

Marcus, Sharon. Between Women: Friendship, Desire, and Marriage in Victorian England. Princeton: Princeton UP, 2007. Print.

Matsuoka, Mitsuharu. "Letters of Elizabeth Gaskell to Charles Dickens." Letters of Elizabeth Gaskell to Charles Dickens. University of Nagoya, n.d. Web. 15 Apr. 2016.

Miles, Robert. "The 1790s: The Effulgence of Gothic." The Cambridge Companion to Gothic Fiction. By Jerrold E. Hogle. Cambridge: Cambridge UP, 2002. 21-40. Print.

The Monthly Review. Vol. 29. London: n.p., 1799. Google Books. Web. 11 Apr. 2016. Moretti, Franco. Distant Reading. Memphis, TN: Verso, 2013. Print.

Morton, Karen. A Life Marketed as Fiction: An Analysis of the Work of Eliza Parsons. Kansas City, MO: Valancourt, 2011. Print. 
Nixon, Cheryl. Novel Definitions: An Anthology of Commentary on the Novel, 16881815. Peterborough, Ont.: Broadview, 2009. Print.

Potter, Franz J. The History of Gothic Publishing, 1800-1835: Exhuming the Trade. Houndmills, Basingstoke, Hampshire: Palgrave Macmillan, 2005. Print.

Radcliffe, Ann Ward, Terry Castle, and Bonamy Dobrée. The Mysteries of Udolpho. Oxford, England: Oxford UP, 2008. Print.

Rees, Thomas, and John Britton. Reminiscences of Literary London from 1779 to 1853 ; with Interesting Anecdotes of Publishers, Authors and Book Auctioneers of That Period ; Ed. by a Book Lover. London: Suckling \& Galloway, 1896. Print.

Rees, Thomas, and John Britton. Reminiscences of Literary London from 1779 to 1853 ; with Interesting Anecdotes of Publishers, Authors and Book Auctioneers of That Period ; Ed. by a Book Lover. London: Suckling \& Galloway, 1896. Print.

Rosenblum, Dolores. "Face to Face: Elizabeth Barrett Browning's Aurora Leigh and Nineteenth-Century Poetry." Victorian Studies 26.3 (1983): 321-39. Web.

Rybicki, J., and M. Eder. "Deeper Delta across Genres and Languages: Do We Really Need the Most Frequent Words?" Literary and Linguistic Computing 26.3 (2011): 315-21. Web.

Smollett, Tobias. The Critical Review. Vol. 37. London: S. Hamilton, 1803. Print. Smollett, Tobias George. The Critical Review. Vol. 21. N.p.: London, 1797. Google Books. Web. 10 Apr. 2016.

Smollett, Tobias. The Critical Review. Vol. 16. London: n.p., 1796. Google Books. Web. 10 Apr. 2016. 
Stone, Marjorie. "Genre Subversion and Gender Inversion: "The Princess" and "Aurora Leigh"" Victorian Poetry 25.2 (1987): 101-27. Web. 15 Apr. 2016.

Townshend, Dale, and Angela Wright. Ann Radcliffe, Romanticism and the Gothic. N.p.: Cambridge UP, 2014. Print.

Tucker, Herbert F. Epic: Britain's Heroic Muse, 1790-1910. Oxford: Oxford UP, 2008.

Print.

Voller, Jack G. "Misstated Identity in Gaskell's 'The Old Nurse's Story"' Notes and Queries 56.3 (2009): 398-99. Web.

Woolf, Virginia. A Haunted House, and Other Short Stories. New York: Harcourt Brace Jovanovich, 1972. Print. 


\section{Appendix:}

\section{Graphs for Section 1.2}

\section{1: Euclidean Distance from Minerva Corpus}

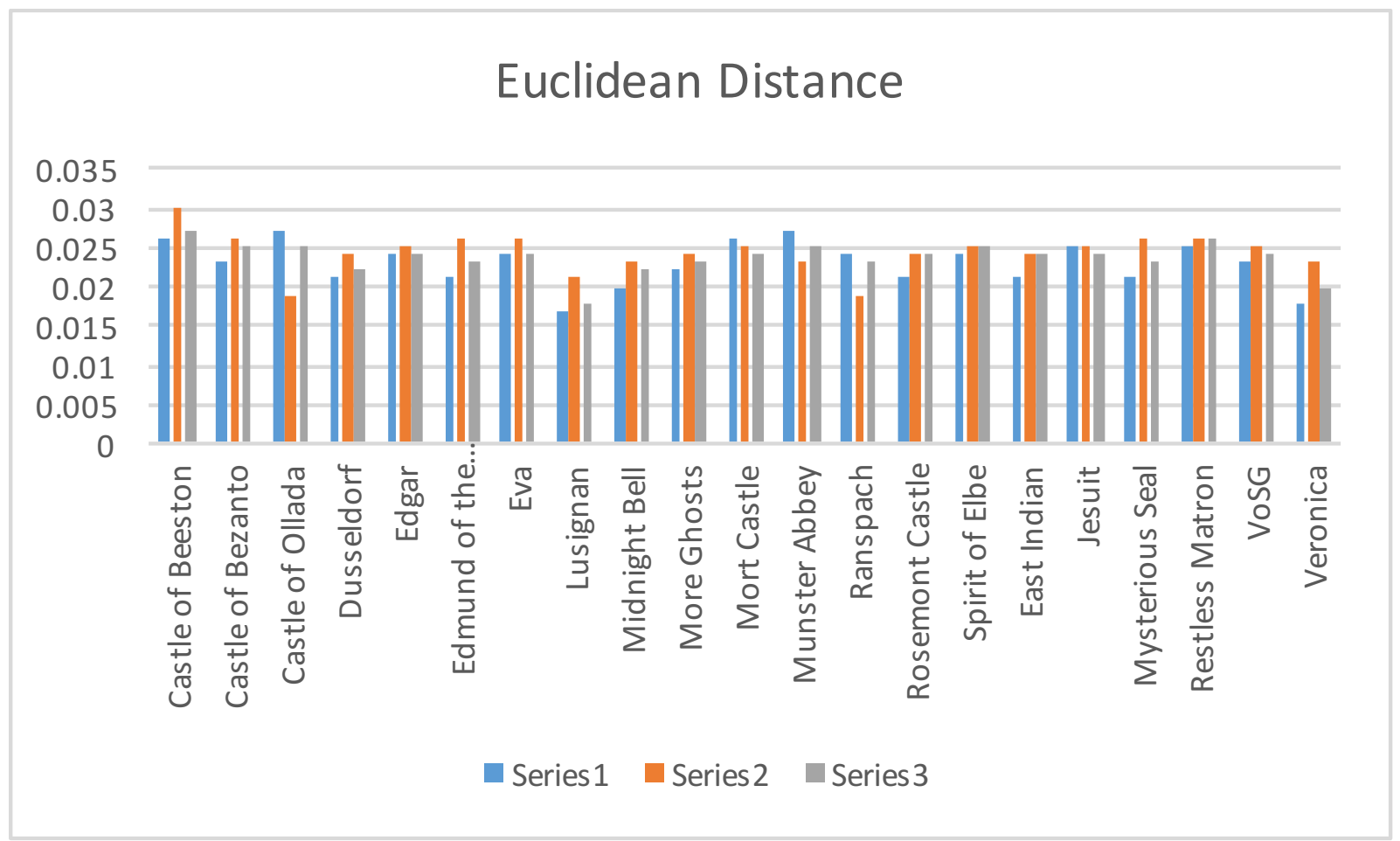

\begin{tabular}{|l|r|r|r|}
\hline & Series 1 (Udolpho) & Series 2 (The Monk) & Series 3 (The Italian) \\
\hline Castle of Beeston & 0.026 & 0.03 & 0.027 \\
\hline Castle of Bezanto & 0.023 & 0.026 & 0.025 \\
\hline Castle of Ollada & 0.027 & 0.019 & 0.025 \\
\hline Dusseldorf & 0.021 & 0.024 & 0.022 \\
\hline Edgar & 0.024 & 0.025 & 0.024 \\
\hline Edmund of the & 0.021 & 0.026 & 0.023 \\
\hline Forest & 0.024 & 0.026 & 0.024 \\
\hline Eva & 0.017 & 0.021 & 0.018 \\
\hline Lusignan & & &
\end{tabular}




\begin{tabular}{|l|r|r|r|}
\hline & Series 1 (Udolpho) & Series 2 (The Monk) & Series 3 (The Italian) \\
\hline Midnight Bell & 0.02 & 0.023 & 0.022 \\
\hline More Ghosts & 0.022 & 0.024 & 0.023 \\
\hline Mort Castle & 0.026 & 0.025 & 0.024 \\
\hline Munster Abbey & 0.027 & 0.023 & 0.025 \\
\hline Ranspach & 0.024 & 0.019 & 0.023 \\
\hline Rosemont Castle & 0.021 & 0.024 & 0.024 \\
\hline Spirit of Elbe & 0.024 & 0.025 & 0.025 \\
\hline East Indian & 0.021 & 0.024 & 0.024 \\
\hline Jesuit & 0.025 & 0.025 & 0.024 \\
\hline Mysterious Seal & 0.021 & 0.026 & 0.023 \\
\hline Restless Matron & 0.025 & 0.026 & 0.026 \\
\hline VoSG & 0.023 & 0.025 & 0.024 \\
\hline Veronica & 0.018 & 0.023 & 0.02 \\
\hline
\end{tabular}

\section{2: PCA at 1000 MFW}

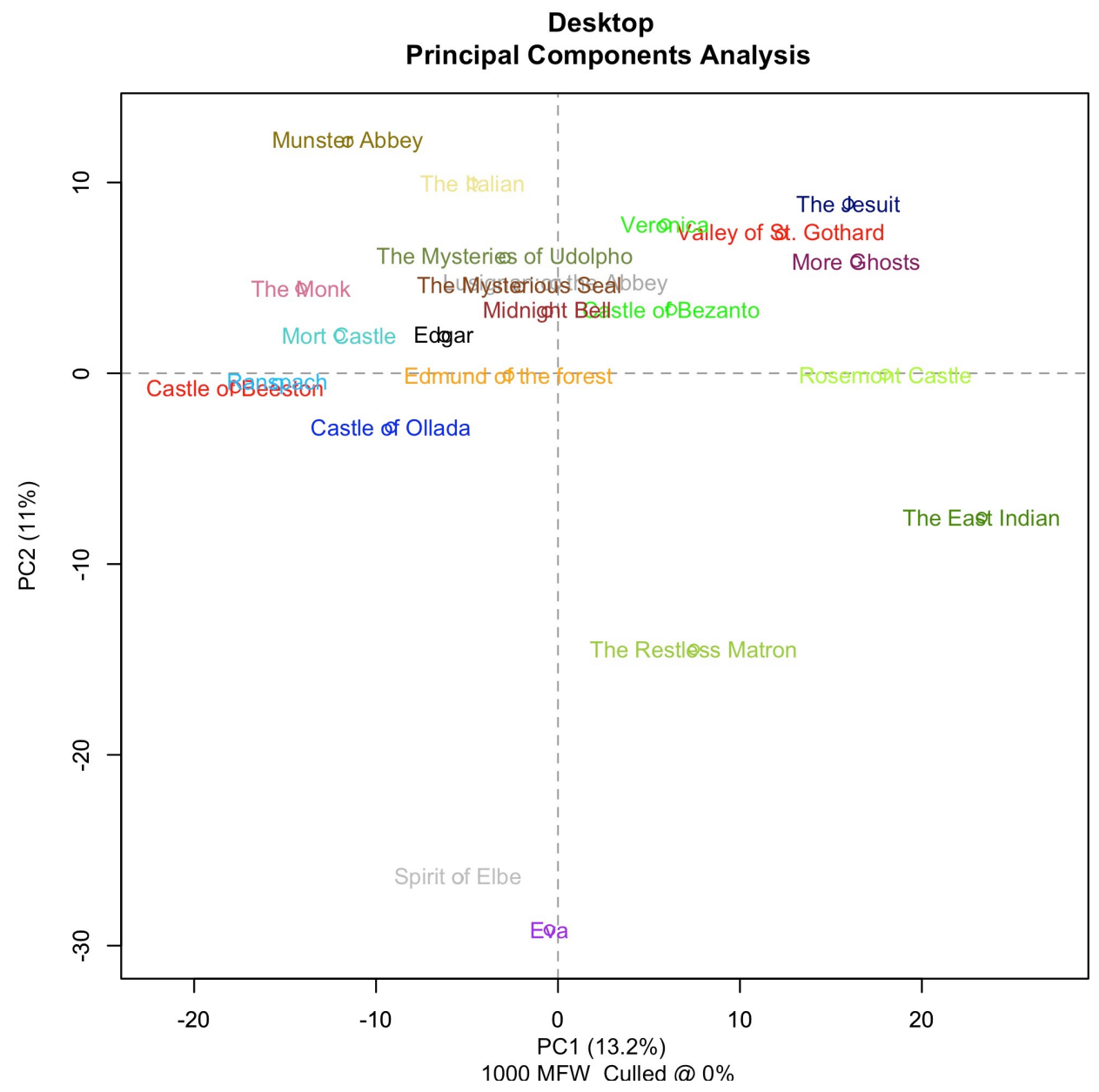




\section{3: Burrow's Delta: Cluster Analysis at 50 MFW}

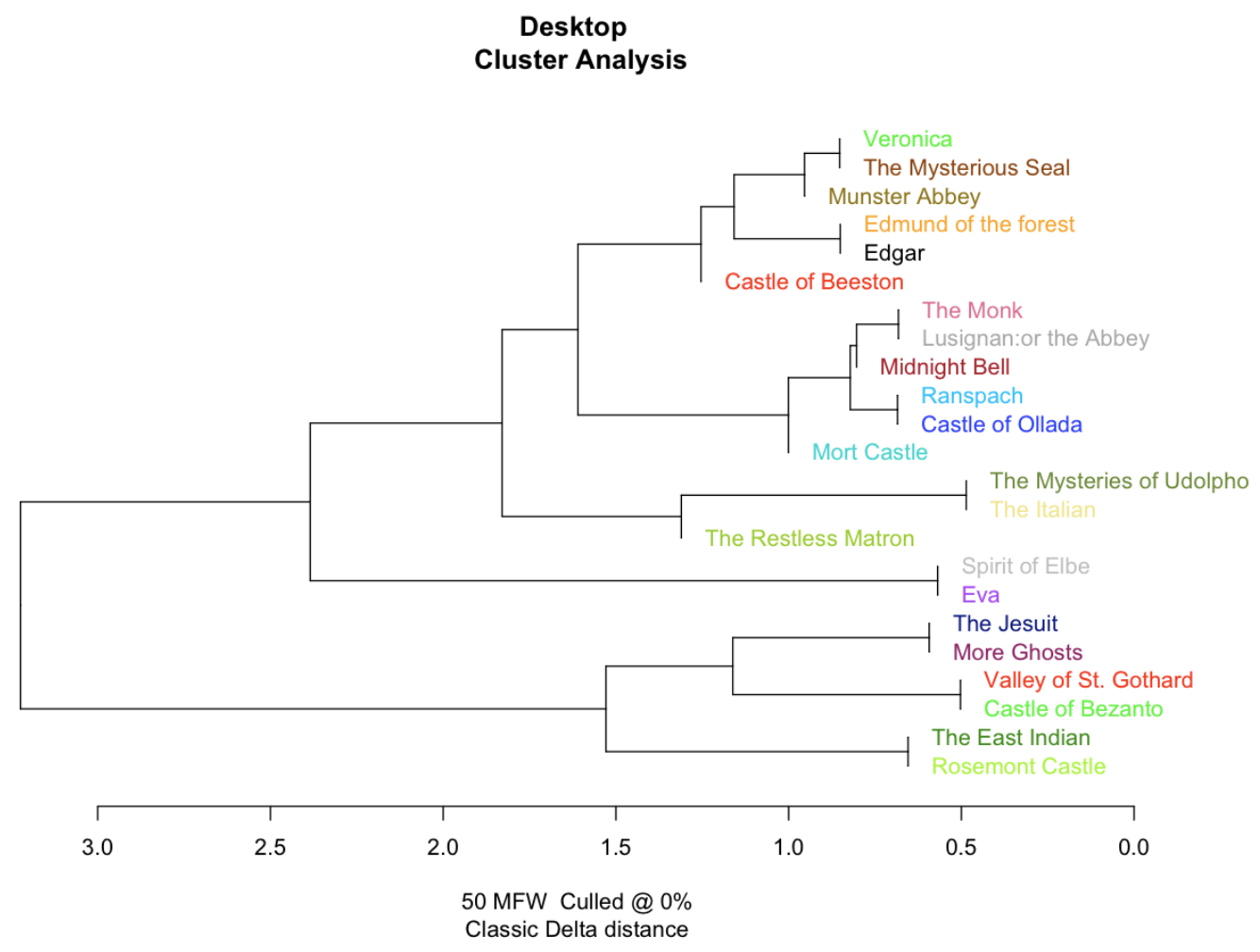

\section{Graphs for Section 1.3}

\section{1: Word Frequency per 10,000 Words w/ Standard Deviation}

\begin{tabular}{|c|c|c|c|c|c|c|}
\hline $\begin{array}{l}\text { The } \\
\text { Italian }\end{array}$ & $\begin{array}{l}\text { Castle of } \\
A\end{array}$ & $\begin{array}{l}\text { Romance } \\
\text { of } F\end{array}$ & $\begin{array}{l}\text { Sicilian } \\
\text { Rom }\end{array}$ & Udolpho & Lusignan & \\
\hline 4693.12 & 4890.51 & 4647.4 & 4700.4 & 4706.12 & 4555.04 & 4698.765 \\
\hline-4698.76 & -4698.76 & -4698.76 & -4698.76 & -4698.76 & -4698.76 & \\
\hline-5.64 & 191.75 & -51.36 & 1.64 & 7.36 & -143.72 & \\
\hline \multirow[t]{2}{*}{31.81} & 36768.06 & 2637.85 & 2.69 & 54.17 & $20,655.44$ & 60150.02 \\
\hline & & & & & & 245.26 \\
\hline-0.02 & 0.78 & -0.21 & 0.01 & 0.03 & -0.59 & \\
\hline
\end{tabular}




\title{
2.2: Cluster Analysis for $18 / 19$ C Corpus
}

\author{
Desktop \\ Cluster Analysis
}

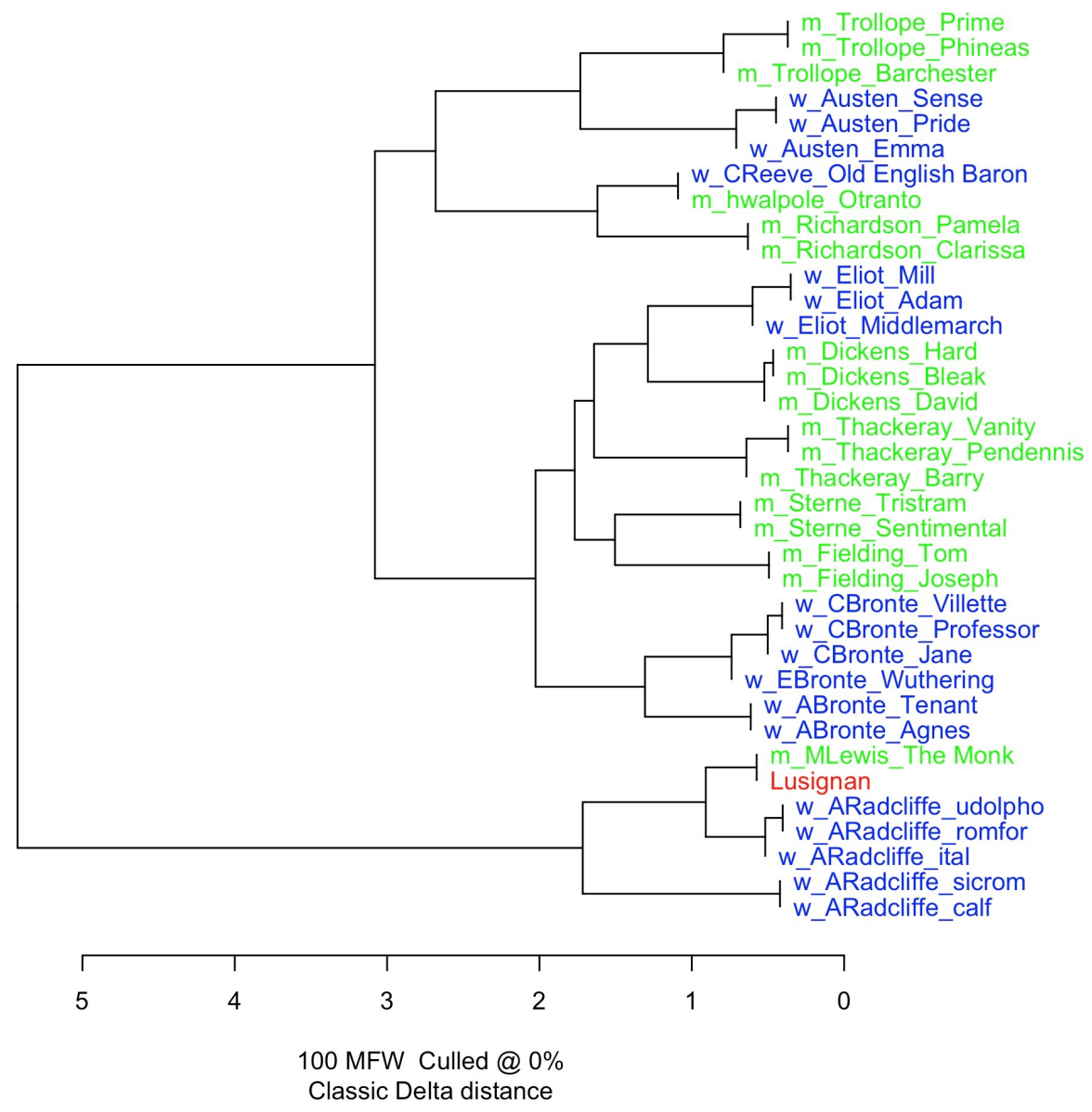

\section{3: PCA for 18/19 C Corpus}

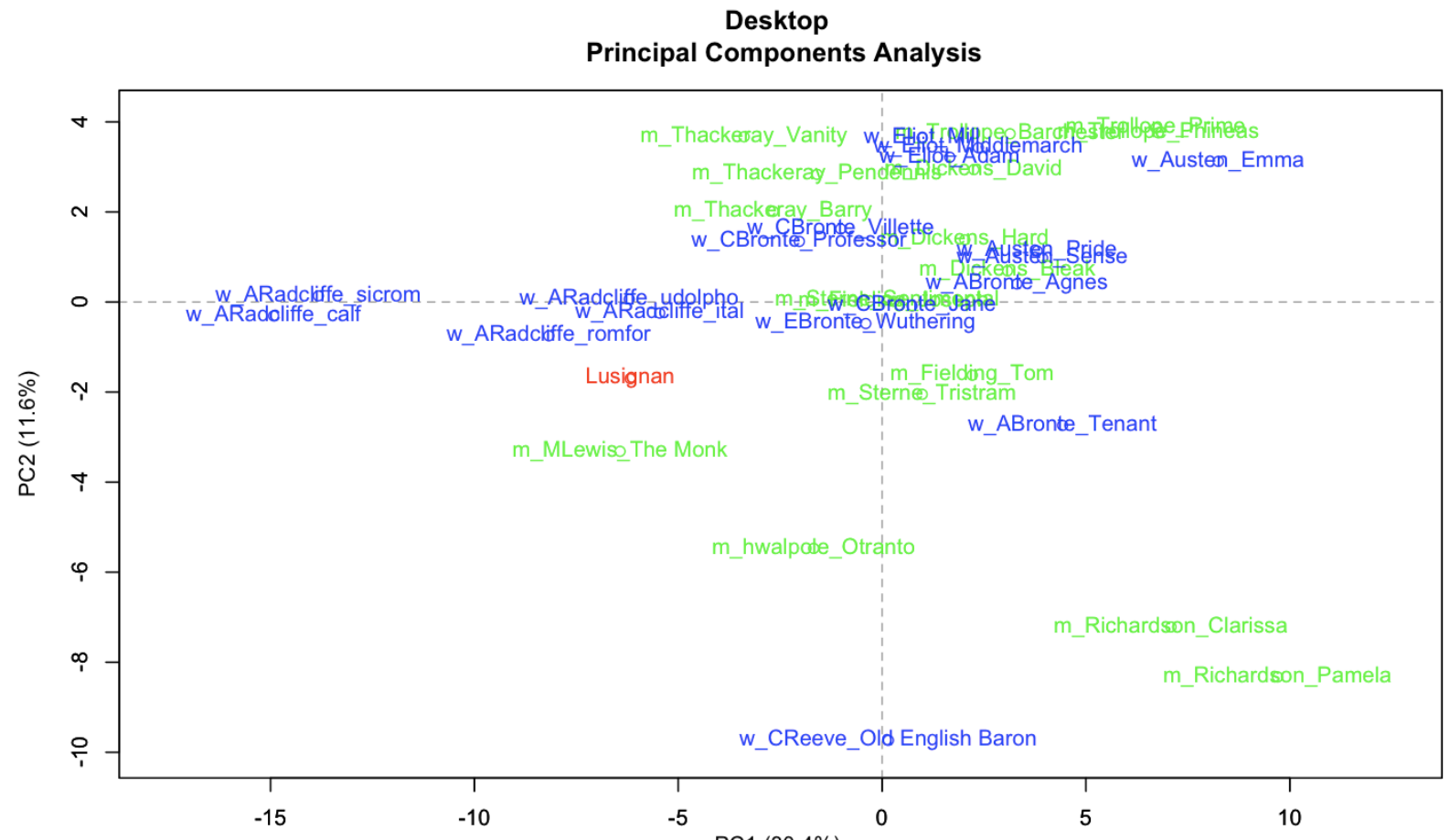




\section{4: Cluster Analysis for $18 \mathrm{C}$ Corpus}

\section{Cluster Analysis}

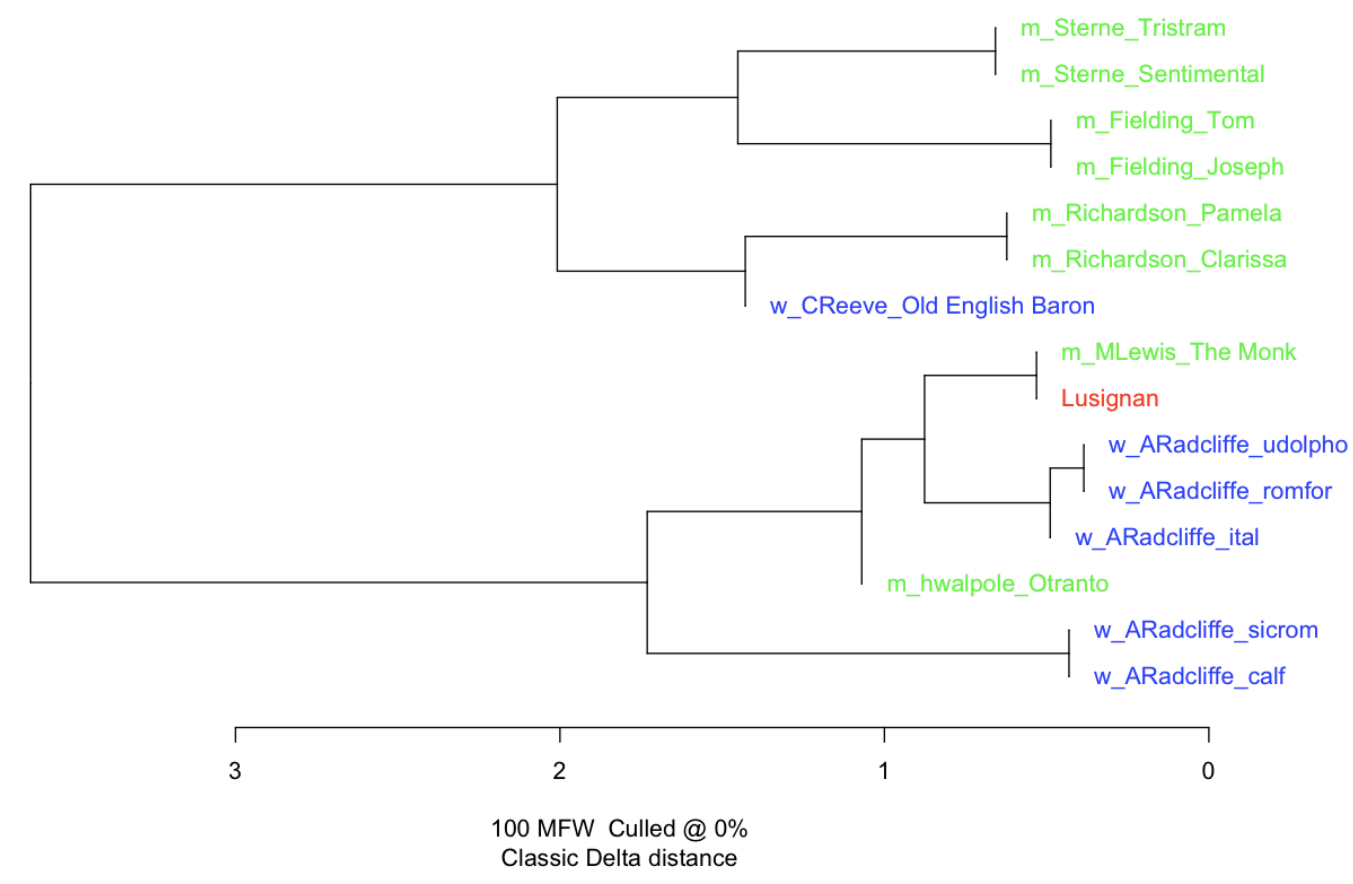

\section{5: PCA for $18 \mathrm{C}$ Corpus}

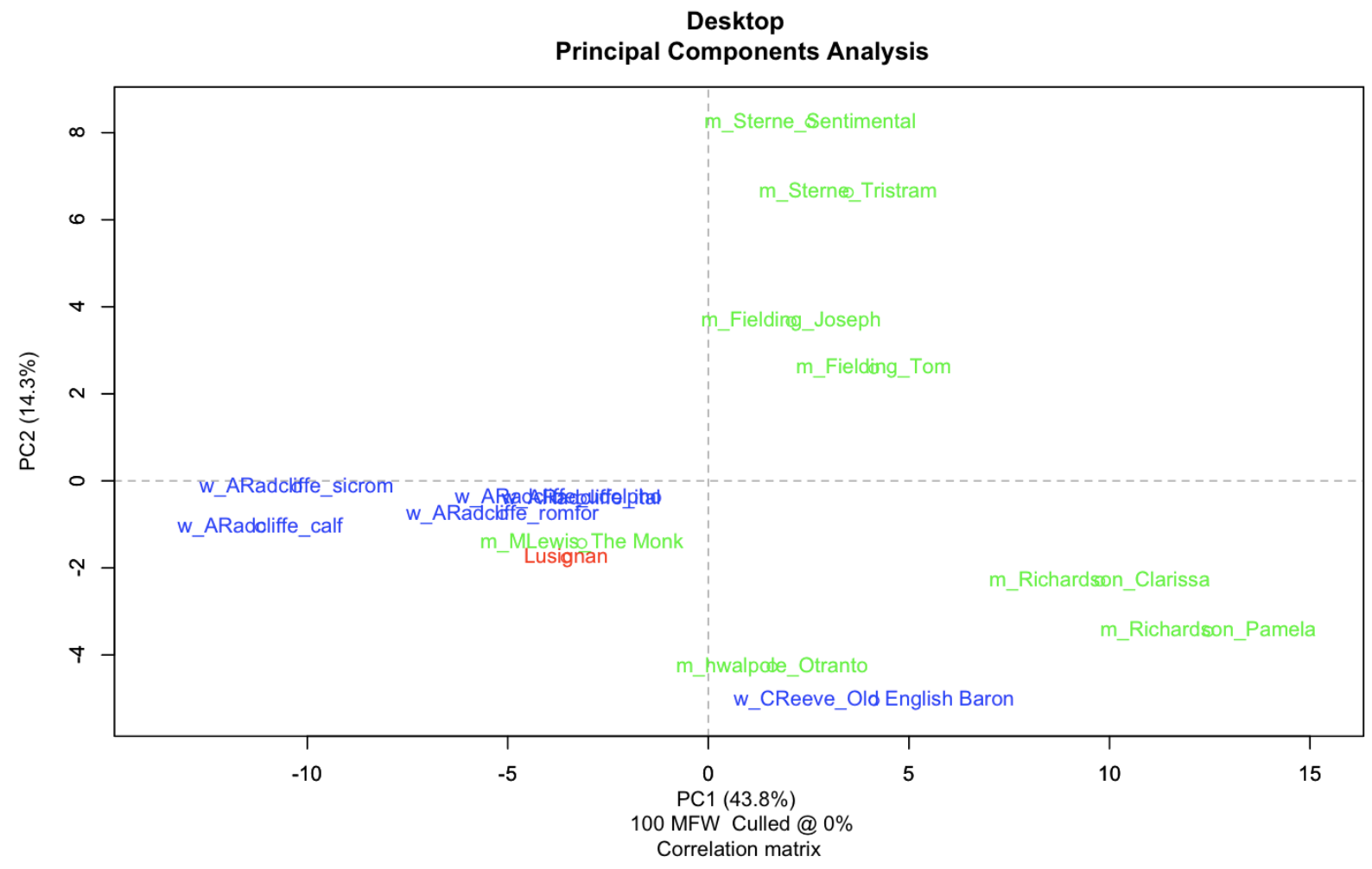




\title{
Word Lists for Section 1.4
}

\section{Topic Models:}

\author{
Lusignan
}

$0 \quad 10$ succeeded life attended hand god enquired bentivoglio approached free returned crime vows past lover castle sought pierre duchess coming

110 time lusignan emily heaven madame paris tears side human perfectly dorimond length venerable assistance answered requested prospect clouds contempt

210 heart appeared neglected souls stranger tears great haye la opinion elapsed recollection intelligence sufferings vain appearance owed duke bell

310 found meronville de apartment door clarival hour meet days gratitude moment surely feelings compared evening told mind offered communicate

410 eyes day fixed father leave success morning insensible receded anguish fatal attachment anxious misery st delicate wished thing interview

$<1000>$ LL/token: -9.70967

Udolpho

Perception 10 heard voice melancholy scarcely moment till air casement countenance looked round found fear stood proceeded music hand carriage morning

Movement 10 night count valancourt tears returned passed aunt appeared withdrew heart began madame advanced repose thought observed stopped paused window

210 immediately apartment hour return sunk grief trees led woods emotions silent awakened late scene father remained hastily subject curiosity

310 emily aubert door moments support leaned hope long chateau courage evening fancy occurred sweetness made left endeavoured young ludovico

410 montoni annette st chamber mind spirits silence scenery terrace rose retired length light dorothee appearance entreated confirmed room castle

Combined: 
$0 \quad 10$ emily heard st annette voice madame appeared till hand melancholy countenance moments support silence air de made looked led 110 count hour found eyes life sunk hope passed long scarcely proceeded began thought observed rose light side woman casement 210 apartment heart moment return time spirits enquired aunt castle withdrew scenery leaned anguish endeavoured fell meet room evening fancy

310 montoni tears mind meronville morning attended repose sweetness feelings entered chateau heaven god length approached rising opinion days recollection

$4 \quad 10$ night door aubert chamber valancourt day grief opposite lusignan succeeded appearance surprise returned carriage scene pleasing advanced emotions united

\section{1: Recovery in Udolpho}

The vacant mind is ever on the watch for relief, and ready to plunge into error, to escape from the languor of idleness.

Emily only was absent; who, overcome with the scene she had just witnessed, had retired to her closet to weep alone.

This good woman seemed very willing to accommodate the strangers, who were soon compelled to accept the only two beds in the place.

For a moment she paused in terrified perplexity, till a sense of her father's condition again overcoming every consideration for herself, she proceeded.

Emily had turned to the window, that he might not perceive her anguish; she now understood, that his sight had failed him.

When he had given her his blessing, and it seemed to be the last effort of expiring life, he sunk back on his pillow.

On the edge of the little green, that spread before the cottage, were cattle and a few sheep reposing under the trees.

Not an object, on which her eye glanced, but awakened some remembrance, that led immediately to the subject of her grief.

After this hour her mind became far more tranquil and resigned, than it had been since the marriage of Montoni and her aunt.

These brought to her recollection the prospects among the Pyrenees, which they had admired together, and had believed nothing could excel in grandeur. 
Emily received, about the same period, a much more interesting letter, and which soothed for a while every anxiety of her heart.

How often did she remember the parting scene with Valancourt, and wish, that the Italian had mentioned Montoni's character with less reserve!

This brought to her recollection the veiled picture, which had attracted her curiosity, on the preceding night, and she resolved to examine it.

She had scarcely strength to remove from the room, and regain her own; and, when arrived there, wanted courage to remain alone.

The sight of it called up many interesting reflections, but the melancholy sweetness of the countenance soothed the emotions, which these had occasioned.

In a few moments, the tide of life seemed again to flow; she began to breathe more freely, and her senses revived.

Emily had been some time in her apartment, before the tumult of her mind allowed her to remember several of the past circumstances.

Occupied by melancholy reflections and by anticipations as sad, she did not retire immediately to rest, but leaned thoughtfully on her open casement.

The event immediately following it appeared to justify the assertion, and a superstitious impression had remained on Emily's mind, which the present appearance confirmed.

On reviving, she found herself supported by the stranger, who was watching over her recovery, with a countenance of ineffable tenderness and anxiety.

She watched to a late hour, when, no sound having renewed her fears, she, at length, sunk to repose.

At the mention of this, Emily trembled, and looked anxiously, remembering the spectacle she had herself witnessed there with Dorothee.

Some circumstances of an extraordinary nature now withdrew Emily from her own sorrows, and excited emotions, which partook of both surprise and horror.

\section{2: Recovery in Lusignan}

When she recovered, to her infinite surprise she found herself in her own apartment, without the least appearance of having quitted it. 
Sleep, which flies only from the pillow of guilt, soon brought relief,- -she sunk in sweet oblivion of care.

Trusting this to the care of Providence, we took precautions only against human beings, one of us watching whilst the other slept.

We had reason to remember Theodore Velasquez with infinite gratitude, for without him we must have perished,-in one instance particularly.

Before he retired, it appeared to him advisable to solicit an interview with the Lady Abbess, which was readily granted.

She was happy to comply, and found herself so refreshed by the morning air, that at breakfast she was unusually cheerful.

Sobs and convulsive groans echoed front all parts of the apartment; soon, however, she again revived, and endeavoured to speak.

She resolved to repine no more, but closing her wearied eyelids, forgot in ideal bliss, real and effective misery.

She felt indeed a mournful pleasure in the contemplation, which she would not have exchanged for the boasted ease of the philosopher.

Doubtful and perplexed, she turned her thoughts towards Switzerland, to which she had often looked forward as a temporary asylum.

But absence, she knew, would obliterate the remembrance of scenes, whose recollection could now be only a source of grief.

Bentivoglio leaned back in the carriage, and seemed occupied in ruminations, that prevented his observing the beauty' of the landscapes around.

He found himself cruelly undeceived at the moment when it became most necessary to free his heart from an attachment fatal to its repose.

\subsection{Travel in Lusignan}

Madame de Clarival was soon to return to Paris, as the extreme heat of the weather prevented her remaining in the south

His heart beat when he knocked at the door; he enquired for the Count-he had left Paris early in the morning. 
He alighted at the outward gate; his conductor pulled a bell, whose long reverberating sound seemed echoed on the opposite shores.

Arrived at Paris, he was introduced to the closet of the Duke of Meronville, who eagerly enquired the success of his mission

Early in the morning his Grace with his retinue proceeded towards the metropolis, leaving our disconsolate exile to his melancholy rumination.

Lusignan asked leave to accompany his father to Paris, which was granted without difficulty, and they all set out together

Benedoit seated by his side, and his companion on the box, it drove off with the rapidity of lightning.

-She called for assistance; Gabriella and the faithful St Pierre attended;--they sought her through the innumerable apartments of the Castle.

Soon after the door of the apartment opened, and Madame de Bentivoglio, leaning on the arm of Dorimond, entered.

He was conveyed to one of three the dungeons of the Castle, while they returned to fetch their master and the Marchioness.

\subsection{Travel in Udolpho}

The recollections subdued him, and he abruptly rose from his seat, and walked away to where no eye could observe his grief.

A solemn expression characterized the feelings of St Aubert; tears often came to his eyes, and he frequently walked away from his companions.

After traversing these regions for many leagues, they began to descend towards Rousillon, and features of beauty then mingled with the scene.

The road wound up an ascent, that was clothed with wood, and, instead of following the carriage, they entered the refreshing shade.

Valancourt started from his chair, and went to the window; it was indeed the carriage, and he returned to his seat without speaking.

They reached the romantic town of Leucate early in the day, but St Aubert was weary, and they determined to pass the night there. 
She passed immediately to the chamber, where the remains of her father were laid, and yielded to all the anguish of hopeless grief.

The abbess led her from the church into her own parlour, and there administered all the consolations, that religion and gentle sympathy can give.

While she hesitated, the veil disappeared, and, in the next moment, ashamed of her fears, she returned to the church.

She stopped, leaned for support against a tree, and wept for some minutes, before she had recovered herself sufficiently to proceed.

They walked down to the terrace, where Valancourt was charmed with the river scenery, and the views over the opposite shores of Guienne.

Meanwhile, the travellers pursued their journey; Emily making frequent efforts to appear cheerful, and too often relapsing into silence and dejection.

One evening, having excused herself from accompanying her aunt abroad, she thus withdrew to the pavilion, with books and her lute.

Madame Cheron forbore to mention him to Emily, and, as soon as they reached the chateau, they separated for the night.

The barge stopped before the portico of a large house, from whence a servant of Montoni crossed the terrace, and immediately the party disembarked.

Soon after his arrival, he ordered his gondola, and, with Cavigni, went out to mingle in the scenes of the evening.

The airy groups, which had danced all night along the colonnade of St Mark, dispersed before the morning, like so many spirits.

The sun was now gaining fast upon the sky, and the party quitted the gardens, and retired to repose.

Emily's efforts, therefore, were as unsuccessful as they had been with Montoni, and she withdrew to her apartment to think and weep alone.

While she thus leaned, Montoni, followed by two men, appeared, ascending a winding path, cut in the rock below.

As she hastily passed the folding doors from the terrace, towards her own apartment, several persons entered the hall by an opposite door. 
The cavaliers supped by themselves, and Madame Montoni remained in her apartment, whither Emily went, before she retired to her own.

On the morning of her journey, Count Morano had gone at the appointed hour to the mansion of Montoni, to demand his bride.

As she sauntered on the rampart, Annette appeared at the hall door, looked cautiously round, and then advanced to meet her.

Leaving the gay scenes of Paris, we return to those of the gloomy Apennine, where Emily's thoughts were still faithful to Valancourt.

Soon after, Emily heard the door fastened on the inside, and she withdrew to her chamber, wondering at what she had witnessed.

On the following morning, Emily went early to the apartment of Madame Montoni, who had slept well, and was much recovered.

It was so, and she then stepped timidly out into the gallery, but paused there, uncertain which way she should proceed

It led her to the door of a landing-place, that terminated them, but she was unable to follow it farther.

Emily's heart sunk; but she still followed him, and he turned out of what had been the principal aisle of the chapel.

As they advanced, these vapours thickened, and Barnardine, believing the torch was expiring, stopped for a moment to trim it.

Montoni ordered Emily to await him in the cedar parlour, whither he soon followed, and then sternly questioned her on this mysterious affair.

Of the soldiers, disbanded at the end of every war, few returned to the safe, but unprofitable occupations, then usual in peace.

Emily, however, unwilling to return to her more forlorn chamber, whither Annette was not yet come, still paced the gallery.

Having emerged from the woods, they wound along the valley in an opposite direction to that, from whence the enemy were approaching.

The winding mountains, at length, shut Udolpho from her view, and she turned, with mournful reluctance, to other objects. 
To her affrighted fancy it occurred, that they were leading her into these woods to complete the will of Montoni by her murder.

They again led the mules forward, between the boles of the trees, and over pathless grass, that concealed their high knotted roots.

It was noon, when she had left the cottage, and the evening was closed, long before she came within the neighbourhood of Udolpho.

As Blanche leaned from the coach window, she resigned herself to the sweet and gentle emotions, which the hour and the scenery awakened.

From the silence, into which reflection and expectation had thrown them, they, at length, roused themselves, and left the chamber.

The still gloom of the hour was pleasing to the Count, and he pursued his way through the woods, sunk in deep thought.

Emily also rose at an early hour, and took her customary walk along the brow of the promontory, that overhung the Mediterranean.

When they returned to the chateau, Emily retired to her apartment, and Count De Villefort to the door of the north chambers.

\subsection{Sensation and Perception in Udolpho}

Having come within view of the front of the chateau, a landau, with smoking horses, appeared on the little lawn before it.

St Aubert perceived the liveries of his brother-in-law, and in the parlour he found Monsieur and Madame Quesnel already entered.

It is like the voice of some supernatural being - the voice of the spirit of the woods, that watches over them by night. .

The rays of light fell strongly upon it, and she perceived it to be that of a lady, but not of her mother.

In these regions it was particularly so, where an abundance of wild flowers and aromatic herbs breathed forth their essence on the air.

Mingled woods, and rocks, and heathy mountains were now seen obscurely through the dusk; but soon even these imperfect images faded in darkness.

While many reflections rose upon his mind, he heard a voice shouting from the road behind, and ordering the muleteer to stop. 
The blaze discovered a rude kind of tent, round which many children and dogs were playing, and the whole formed a picture highly grotesque.

Valancourt immediately answered the call, and endeavoured to make his way through the thicket that clothed the steeps, following the direction of the sound.

They passed a few minutes in interesting conversation, and St Aubert then led the way to the carriage, Emily and Valancourt following in silence.

Her perceived her, and waved his hand; and she returned the adieu, till the winding road shut her from his sight.

As his languid eyes moved over the scene, he considered, that they would soon, perhaps, be closed for ever on this world.

St Aubert, on hearing this odd question, and observing the peculiar tone in which it was delivered, looked out from the carriage.

Michael turned about immediately, and was retracing his way with alacrity, when a voice was heard from among the trees on the left.

When the rattling of the wheels had ceased, music was heard on their air; it was to Emily the voice of Hope.

In a few moments the voice died into air, and the instrument, which had been heard before, sounded in low symphony.

She continued to gaze wildly; took up the cold hand; spoke; still gazed, and then burst into a transport of grief.

As she listened, she was chilled with superstitious awe, her tears stopped; and she rose, and went to the window.

Soon after, she observed the planet trembling between the fringed tops of the woods, and, in the next moment, sink behind them.

The bell for vespers struck, as she passed the ancient gate of the convent, and seemed the funereal note for St Aubert.

She scarcely heard the whispering echoes of her own steps, or thought of the open grave, till she found herself almost on its brink.

Valancourt understood her feelings, and was silent; had she raised her eyes from the ground she would have seen tears in his. 
Emily was called from the musing fit, into which she had fallen, by the Count Bauvillers, who was known to her aunt.

From such observations she was the more inclined to believe, that it was this Montoni, of whom the Italian had uttered his suspicious hints.

The first object that attracted her notice was a group of dancers on the terrace below, led by a guitar and some other instruments.

She sung a melancholy little air, one of the popular songs of her native province, with a simplicity and pathos that made it enchanting.

Montoni smiled contemptuously; and Emily, now terrified for the consequences of what she saw and heard, could no longer be silent.

To call off her attention from subjects, that pressed heavily on her spirits, she rose and again examined her room and its furniture.

Emily, whom Annette had now infected with her own terrors, listened attentively; but every thing was still, and Annette proceeded:

She rose, and, to relieve her mind from the busy ideas, that tormented it, compelled herself to notice external objects.

But, when she again looked round her gloomy chamber, and recollected certain circumstances, fear seized her spirits, and she hesitated.

She now screamed in despair, and, believing herself given up by Montoni, saw, indeed, no possibility of escape.

As she was thus employed, she saw, walking on the rampart below, the men, who had so lately arrived at the castle.

As one of these cloaks glanced aside, she saw, beneath, daggers, apparently of different sizes, tucked into the horseman's belt.

Continuing at the casement, that she might catch the last lingering gleam of evening, a thousand vague images of fear floated on her fancy.

For some moments, she stood in an attitude of listening expectation, shrinking almost from herself and scarcely daring to look round her.

The voice came again, but, though it was now near her, terror did not allow her to judge exactly whence it proceeded. 
To her melancholy fancy this seemed to be a place of death, and the chilling silence, that reigned, confirmed its character.

Fear and surprise now yielded to the enchantment of a strain, that floated on the silent night, with the most soft and melancholy sweetness.

She continued to listen, sunk in that pleasing repose, which soft music leaves on the mind-but it came no more.

At length, she left the casement, but her steps faltered, as she approached the bed, and she stopped and looked round.

III as she was, the appearance of this curtain struck her, and she paused to gaze upon it, in wonder and apprehension.

Beyond, appeared a corpse, stretched on a kind of low couch, which was crimsoned with human blood, as was the floor beneath

It was in one of these moments of obscurity, that she observed a small and lambent flame, moving at some distance on the terrace.

In the next moment, she found herself clasped in the arms of some person, and heard a deep voice murmur in her ear.

In a few moments, their soft melody was accompanied by a voice so full of pathos, that it evidently sang not of imaginary sorrows.

Soon after, she heard voices faintly from the halls, and the noise of horses' feet sunk away in the wind; silence ensued.

At length, she heard a footstep approach her chamber; and, on opening the door, saw, not Annette, but old Carlo!

It was now so nearly dark, that the travellers, who proceeded only by the slowest pace, could scarcely discern their way.

Reassured by this circumstance, she advanced towards the sounds, which seemed to arise from behind a high promontory, that projected athwart the beach.

There was now a sudden pause in the music, and then one female voice was heard to sing in a kind of chant.

Annette, meanwhile, as impatient as her mistress, went as often to the casement to listen, and returned almost as much disappointed. 
But soon they heard Ludovico speaking loud, and the voice also of some other person, and Du Pont immediately extinguished the lamp.

Emily started on perceiving her, and hastily put up the papers, but not before Dorothee had observed both her agitation and her tears.

Perceiving her tears and that she was rising to go, Valancourt struggled, once more, to overcome his own feelings and to sooth hers.

Dorothee changed countenance, and, while they both listened, they heard, on the stillness of the night, music of uncommon sweetness.

he appeared greatly shocked to see her, for soon after her death a frightful blackness spread all over her face.

She found the old woman within, picking vine-stalks, who, on perceiving her young mistress, was nearly overcome with joy.

It was apparent, that the people within had heard the sound, and their caution in admitting strangers gave him a favourable opinion of them.

\subsection{Sensation and Perception in Lusignan}

The pathetic and marvellous thus united, was repeated from one to the other, till it reached the ears of Mademoiselle de Montalte.

The boasted eloquence of the eyes, was mutually expressive; and souls congenial like theirs, could not long misunderstand each other.

Gentle melancholy tinged her features, and sorrow was mingled in the smile of benevolence, with which she greeted her fellow-sufferers.

He paused to see the effect of his elaborate preface on the countenance of Lusignan; it had not undergone the least alteration.

Madame de Meronville in a moment saw the injustice of these suspicions, and neglected no pains to convince her husband of it.

The solitary tenant from the wood soon approached, and, uttering an exclamation in our native language, shrieked horribly, and fled.

Yaratilda soon appeared with her brother; they released us from confinement, and, in profound silence, led towards the shore. 
Whilst Emily was enjoying the rapture she had caused in their innocent minds, a gentle tap at the door sued for admittance.

These were the words he had uttered in a transport of rage, and these were deeply engraven on the memory of La Haye.

Emily, thinking her terrified Abigail's alarm might be connected with her own, desired her to explain what she had seen.

Emily sat perfectly mute during this relation; her countenance exhibited no marks of animation, nor did she utter a single groan.

He whispered his gratitude, and ventured to request implements for writing, but he was answered only by a shake of the head.

In listening to the maternal raptures of her friend, and almost partaking them, she found an undefinable increase of happiness.

To these violent exertions succeeded two days of obstinate silence, during which he refused all sustenance; the third endangered his life.

Meronville alone was Insensible to his danger; so inconsiderable are the tortures of the body compared with those of the mind.

To the eye, the ear, the heart, and all the subject senses, death in every horrid shape presented itself.

\subsection{Sentiment in Udolpho and Lusignan}

\section{Udolpho}

His heart was occupied; it had, what can be so rarely said, no wish for a happiness beyond what it experienced.

St Aubert, calm and deliberate, preserved his dignity without assuming importance, and Quesnel was depressed by his presence without exactly knowing wherefore.

The chairs, the tables, every article of furniture, so familiar to her in happier times, spoke eloquently to her heart.

It was of uncommon beauty, and was characterized by an expression of sweetness, shaded with sorrow, and tempered by resignation.

She feared to trust the preference her heart acknowledged towards Valancourt, and to give him any encouragement for hope, on so short an acquaintance. 
She could not conquer a presentiment, which frequently occurred to her, this night-that she should never more return to La Vallee.

It was in vain, that she endeavoured to subdue her grief, and resign herself to an event, which she could not avoid.

The information she had just received excited, perhaps, more alarm than it could justify, and raised once more the conflict of contrasted interests.

How often did she wish to express to him the new emotions which this astonishing scenery awakened, and that he could partake of them!

She forgot all she would have said, and neither enquired for her aunt, or entreated for Annette, but stood silent and embarrassed.

The feelings of his comrade seemed to be very opposite, and adapted rather to the cruelties, than to the dangers of war.

Emily, still more alarmed, began now to fear, that Dorothee was seized with sudden phrensy, but entreated her to explain herself.

\section{Lusignan:}

She was surprised at the degree of indolence she felt, and at her disinclination to dress, and go to the rooms.

She sometimes succeeded, and began to hope her influence might be productive of reformation; but some secret power counteracted all her endeavours.

He behaved with unusual civility and even obsequiousness to Lusignan, who was at no pains to disguise or suppress his profound contempt.

Nature raised a few scruples in his heart, and he had felt a pang of remorse at the sufferings of his only child. 
